\title{
The immunomodulatory role of carbon monoxide during transplantation
}

\author{
Mariane Tami Amano and Niels Olsen Saraiva Camara
}

\begin{abstract}
The number of organ and tissue transplants has increased worldwide in recent decades. However, graft rejection, infections due to the use of immunosuppressive drugs and a shortage of graft donors remain major concerns. Carbon monoxide (CO) had long been regarded solely as a poisonous gas. Ultimately, physiological studies unveiled the endogenous production of $\mathrm{CO}$, particularly by the heme oxygenase (HO)-1 enzyme, recognizing $\mathrm{CO}$ as a beneficial gas when used at therapeutic doses. The protective properties of CO led researchers to develop uses for it, resulting in devices and molecules that can deliver $\mathrm{CO}$ in vitro and in vivo. The resulting interest in clinical investigations was immediate. Studies regarding the $\mathrm{CO} / \mathrm{HO}-1$ modulation of immune responses and their effects on various immune disorders gave rise to transplantation research, where $\mathrm{CO}$ was shown to be essential in the protection against organ rejection in animal models. This review provides a perspective of how CO modulates the immune system to improve transplantation and suggests its use as a therapy in the field.
\end{abstract}

Keywords: $\mathrm{CO}, \mathrm{HO}-1$, Immune response, Transplant

\section{Review}

\section{Transplantation}

End-stage organ failure often requires transplantation, and the number of solid organ transplants reached 106,900 worldwide in 2010 according to the Global Observatory on Donation and Transplantation (www.transplant-observatory.org). One of the most common solid organ transplants is the kidney. Even for renal diseases that can be treated with various therapies, transplants increase the quality of life in most cases and are a financially attractive solution. More than 73,000 kidney transplants were performed in 2010; in comparison, approximately 21,000 liver transplants were performed (www.transplant-observatory. org). Although there are a high number of solid organ transplants, graft loss following chronic allograft dysfunction is still a major concern during transplantation [1,2]. For cases in which chronic rejection does not occur, sideeffects due to the use of immunosuppressants are the main cause of mortality [3]. A third concern is the shortage of organs that has forced the donor pool to include extended criteria and non-heart beating donors, which are more susceptible to delayed graft function (DGF) [4]. All

\footnotetext{
* Correspondence: niels@icb.usp.br

Laboratory of Transplantation Immunobiology, Department of Immunology, Institute of Biomedical Sciences, University of Sao Paulo, Sao Paulo, Brazil
}

of these complications reinforce the search for new transplantation therapies.

\section{Immune system in ischemia and reperfusion}

The immune system is divided into the innate and adaptive immune responses. The innate immune response is known as the first line of defense, and it depends mostly on inflammatory components. It is faster and less specific than the adaptive response. In contrast, the adaptive response involves the participation of lymphocytes, and it generates memory. It takes longer to build an adaptive response, but such responses are more specific than innate responses. While adaptive immune responses are an excellent system for fighting pathogens, they are also very effective against allograft acceptance. In solid organ transplantation, the graft is subjected to ischemia prior to being transplanted. Ischemia and reperfusion (IR) is the first step in which the immune system acts to avoid the survival of the graft. Ischemia is defined as the cessation of arterial blood flow, which leads to oxygen deprivation of the cells. Cold ischemia is most often used in transplantation, whereby the organ is harvested and kept in a cold solution. There is also warm ischemia, which involves the blockade of blood flow by trauma, such as during a stroke [5]. IR causes cell damage [6,7],
C Biomed Central

(c) 2013 Amano and Camara; licensee BioMed Central Ltd. This is an Open Access article distributed under the terms of the Creative Commons Attribution License (http://creativecommons.org/licenses/by/2.0), which permits unrestricted use, distribution, and reproduction in any medium, provided the original work is properly cited. 
and it is associated with DGF and primary graft nonfunction $[8,9]$.

Microvascular damage initiates inflammation by upregulating complement [10], Toll-like receptors (TLRs) [5], TLR ligands [9], and leukocyte adhesion molecules [11].

The complement system is a cascade of proteins that participates in the inflammatory response and produces the membrane attack complex (MAC). C5a, one of the products of complement activation, is involved in IR injury by attracting and stimulating the degranulation of neutrophils, as well as upregulating CXC-motif chemokines [12]. Blockade of the C5a receptor during cold ischemia impairs IR damage by diminishing tubular cell apoptosis [13]. MAC formation can lead to cell lysis, but it can also activate tubular epithelial cells [14-16] to upregulate proinflammatory and fibrotic factors, such as IL-6, TNF, ICAM-1 and collagen [14-17]. The complement inhibitor decay-accelerating factor (DAF) was shown to be absent in mice that are more susceptible to MAC-induced microvascular injury following IR [18]. The deposition of MBL, C3, C6 and C9 in the kidney following IR [19] and the deficiency of Crry (a C3 inhibitor) increased the susceptibility of mice to kidney IR injury [20], corroborating the notion that complement activation during IR contributes to the inflammatory response.

TLRs are a component of the innate immune response because they recognize pathogen- and damage-associated molecular patterns, and they have been implicated in several inflammatory diseases. The absence of TLR4 and/or TLR2 protects mice from IR injury, improving cardiac function [21,22]. TLR2 expression was increased in the liver following IR, and it was associated with higher levels of TNF [23]. However, the lack of TLR2 was not able to protect animals from liver IR injury, while TLR4-deficient animals were protected. This protection was associated with reduced levels of TNF, and it was shown to be dependent on intrahepatic HO-1 expression [24]. TLR2and MyD88 (adapter protein for most TLRs)-deficient mice displayed decreased tubular epithelial apoptosis, cellular infiltration and dysfunction $[25,26]$. TLR4 $^{-/-}$animals were also protected from IR with improved renal function, diminished chemokine production and fewer cellular infiltrates $[27,28]$. The increase in TLR4 following IR was accompanied by an upregulation of HMGB-1, hyaluronan and brevican [27], which suggested that these ligands could be responsible for the downstream activation of TLRs, thereby improving the inflammatory response and contributing to IR injury.

Leukocyte adhesion molecules are often associated with cell migration during inflammatory responses. There are three main groups of leukocyte adhesion molecules: integrins (VLA-4, CD11/CD18) [29,30], immunoglobulin super family members (ICAM-1, VCAM-1, CD4, CD8) [31] and selectins (E, P, L-selectin) [32]. In animal models, the administration of monoclonal antibodies against leukocyte adhesion molecules was able to attenuate IR injury in many organs, including the heart, liver and skeletal muscle [33]. The administration of anti-CD11a and anti-CD11b monoclonal antibodies prior to renal ischemia prevented renal injury with lower serum creatinine levels, but it did not abolish neutrophil migration [34]. IR upregulates ICAM-1 expression in the murine kidney, and the absence of this molecule protects animals from IR injury [35]. Although the first two adhesion molecule groups seem to be involved at least partially in IR damage, the selectin group is minimally involved. L-selectin deficient mice presented similar levels of neutrophil infiltration and renal function when compared to wild type controls [36]. These studies confirmed the role of inflammation during IR injury and led us to question the participation of immune cells in this stage of the transplant process.

As mentioned previously, immune cells infiltrate organs during reperfusion. Neutrophils usually accumulate in the organ following IR in mouse models [35,37], and the depletion of this cell type prevents acute kidney injury (AKI) [35]. It remains unclear how neutrophils migrate and become activated in the ischemic organ, but they seem to be fundamental for IFN- $\gamma$ and IL-17 production [37,38]. Invariant natural killer $\mathrm{T}$ (iNKT) cells were also shown to be important for the control of IFN- $\gamma$-producing neutrophils in a renal IR model [37]. iNKT cells are also involved in hepatic IR injury via CD1d activation [39]. In lung IR, these cells are the primary IL-17 producers [40].

Another important innate immune cell is the macrophage. Macrophages are phagocytic, like neutrophils, but they are known as antigen presenting cells (APC) because they present antigens to $\mathrm{T}$ cells. These cells were shown to infiltrate organs via CCR2-CX3CR1 upon ischemia, with a slight delay when compared to neutrophils [41]. The depletion of macrophages by liposomal clodronate prior to IR prevented AKI, and the adoptive transfer of these cells reconstituted the injury $[42,43]$. Neutrophil- and iNKT cell-derived IFN- $\gamma$ is a potent activator of macrophages, leading to increased production of the proinflammatory cytokines IL- $1 \alpha$, IL- 6 , TNF and IL-12 [37].

Dendritic cells (DCs) are also APCs and are considered a bridge between innate and adaptive immunity. Blocking the CD80/CD86 costimulatory molecules to prevent T cell activation reduced AKI [44]. Dong et al. [45] demonstrated that renal DCs were able to activate $\mathrm{T}$ cells from the draining lymph node after IR. In another study [46], they showed that renal DCs displayed elevated expression of activation molecules (CD80, CD86, MHC class II and CD40) following IR, as well as increased expression of IL6, MCP-1 and RANTES. Furthermore, they established that DCs were the main source of TNF in the kidney after IR. DCs and macrophages are the primary cell types that 
express TLRs, which suggests that these cells are partially responsible for the involvement of TLRs during IR injury.

B cells have several similarities with DCs and macrophages in that they also are able to process and present antigen to T cells via MHC class II. B cells contribute to IR injury in several models: intestine, heart, kidney and skeletal muscle [47-52]. Furthermore, B cell-deficient mice are protected from renal IR injury [50,52]. Complement receptor $(\mathrm{CR}) 2$ deficient-mice, which are defective in B-1 cells and are therefore immunoglobulin (Ig) M-deficient, are protected from IR muscle injury [51].

The adaptive immune response depends on a series of events, making it a lengthy process. Therefore, $\mathrm{T}$ cells, the leading actors of this process, had not been frequently associated with IR injury because it is an immediate response. More recently, a collection of studies has changed this idea and suggested an important role of T cells in IR injury. In a rat model of IR, the use of FTY720 (2-amino2-[4-octylphenyl]-1,3-propaneldiol hydrochloride), a synthetic analog of sphingosine that blocks $\mathrm{T}$ cell circulation from the lymph node to the peripheral blood, improved microcirculation, decreased liver damage and decreased IL-6 and TLR4 expression [53]. In lung IR, CD4 ${ }^{+} \mathrm{T}$ cells were shown to have a major role in stimulating chemokine production and neutrophil chemotaxis, which in turn contributed to IR injury [54]. Shigematsu et al. [55] demonstrated that $\mathrm{B}$ cells, $\mathrm{CD} 4^{+}$and $\mathrm{CD} 8^{+} \mathrm{T}$ cells are involved in the proinflammatory and prothrombogenic phenotype of intestinal IR. In the kidney, the elimination of $\mathrm{CD} 4^{+} \mathrm{T}$ cells with MHC class II knockout mice or anti-CD4 antibodies led to improved renal function following IR [56]. The depletion of $\mathrm{CD} 4^{+} \mathrm{T}$ cells, but not $\mathrm{CD} 8^{+} \mathrm{T}$ cells, diminished injury after hepatic and renal IR [57,58]. CD4+ T cells were shown to be autoreactive following IR [59], and the transfer of DO11.10 (TCR OVA-specific) CD4+ T cells to nude mice, which are normally protected from renal IR injury, conferred renal damage [60]. These studies strongly suggest the participation of $\mathrm{CD}_{4}^{+} \mathrm{T}$ cells in IR injury, and this injury seems to be dependent on $\mathrm{T}$ cell activation. However, the specificity of this activation remains unclear.

Altogether, IR is a complex process that involves activation of both the innate and adaptive immune systems, leading to complications in graft acceptance (Figure 1).

\section{Immune system in transplantation}

The general concept of allograft rejection surmises that $\mathrm{T}$ cells react to alloantigens presented by donor and/or recipient APCs to trigger cytotoxicity and inflammation. With new advances in transplant research, the involvement of the immune system in this process has changed. Much like IR injury, the transplantation process is now thought to involve both immune responses [61] (Figure 1). During heart or renal rejection, the complement is activated, and it can be detected in the blood or urine $[62,63]$ and in the graft itself [64]. In human kidney allografts, tubular epithelial cells generate complement components and become the primary target of their activation [65]. In a mouse model of kidney transplantation, kidneys from $\mathrm{C}^{-1-}$ donors survived for a long period in a fully mismatched recipient without any immunosuppression, providing evidence of the role of donor-produced C3 in kidney rejection [66]. Human donors with a natural defect in mannose binding lectin (MBL), a protein associated with complement activation, improved the chance of cardiac allograft acceptance [67], whereas heart donor $\mathrm{DAF}^{-/-}$ mice accelerated graft rejection [68]. These data suggest two mechanisms for the involvement of complement in allograft rejection: the direct activation of complement in epithelial cells or an indirect role of complement by favoring immune cell activation.

Recipients TLR2 ${ }^{-1-}$ and $\mathrm{MyD} 88^{-/-}$mice had chronic allograft damage attenuated. These deficiencies also reduced the infiltration of DCs, macrophages and T cells into the graft, leading to decreased expression of IL-6, IL-10, monocyte chemotactic protein-1 (MCP-1) and IL12. Fibrotic factors were also diminished in these models via decreased collagen types I and III compared to wild type controls [69]. The downregulation of TLR2 and TLR4 by cyclosporine A and Serp-1 co-treatment impaired $\mathrm{T}$ cell and macrophage intragraft infiltration and allowed for indefinite graft survival [70]. It was additionally shown that TLR4 is constitutively expressed in donor organs, and TLR4 and HMGB-1 expression are increased in non-heart beating donor kidneys [71,72]. In liver transplantation, TLR2, TLR4, HSP60 and HSP70 were increased during reperfusion, with a peak at $3 \mathrm{~h}$ [73]. Patients with acute liver transplant rejection have shown increased CD14+TLR2+ monocytes [74]. TLRs are involved in organ transplantation, and their activation may modulate immune cells that contribute to allograft rejection.

Innate NK cells, which are usually associated with protection against tumors and viral infections, were shown to infiltrate grafts during allogeneic heart transplantation. Associated with this infiltration was the upregulation of their receptor NKG2D as well was their ligands retinoic acid early inducible (RAE-1) and minor histocompatibility antigen H60 [75]. In mouse models, NK cells were shown to be important for the tolerance of islet and skin allografts [76,77]. Together with other studies [61], NK cells appear to participate in the graft progress. However, they appear to promote both tolerance and rejection. Therefore, further investigation is required to understand the relevance of these cells in transplantation models.

Adaptive immunity during transplantation has been extensively studied, and its role in allograft tolerance and rejection is well established. $\mathrm{CD}_{4}^{+} \mathrm{T}$ cells have long been known to promote allograft rejection [78]. Although $\mathrm{CD} 8^{+}$ 
$\mathrm{T}$ cells cannot initiate rejection independently, they exert cytotoxic functions via Fas/Fas-L, contributing to the loss of the graft [79]. Valujskikh et al. [80] summarized the mechanisms of $\mathrm{T}$ cell involvement during transplantation. The classical activation of CD80/CD86 on APCs through
T cell CD28 ligation induces cytokine production (IL-2, TNF, IFN- $\gamma$ ) [81], and this is known to lead to allograft rejection. Similarly, CD40/CD154L amplifies T cell activation, which yields the same outcome as costimulation. Other costimulatory molecules seem to function similarly,

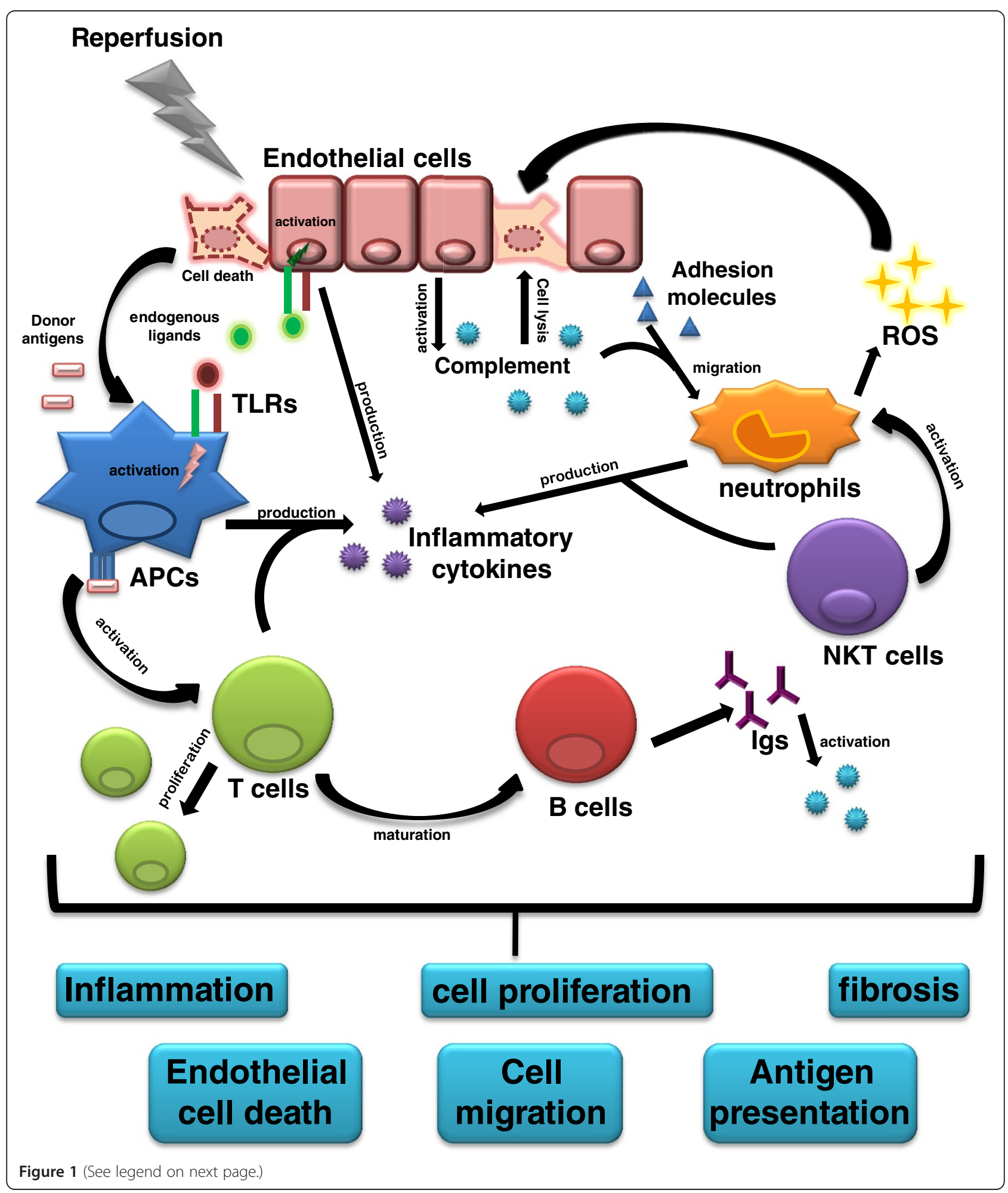




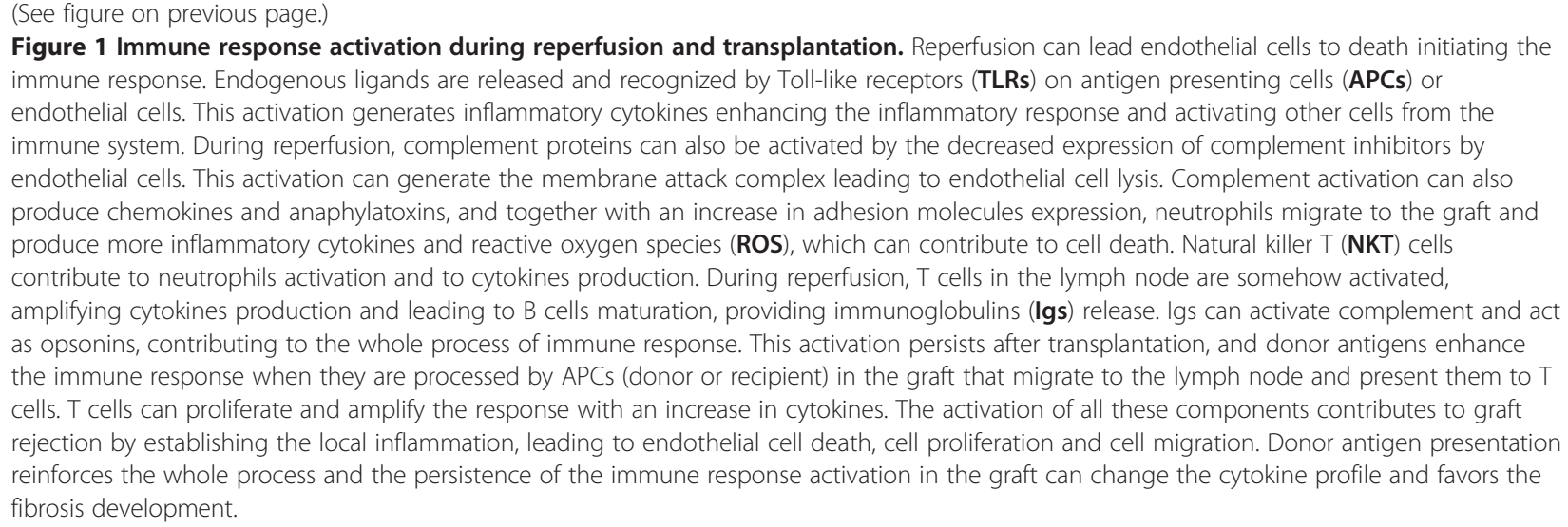

such as the interaction between ICOS/B7RP-1 and CD134/CD134L. Animal studies have shown that blocking the ICOS/B7RP-1 interaction can prolong allograft survival in heart, liver and islet transplantation models [82-86]. Although the disruption of the CD134/CD134L interaction was not able to provide long-term graft survival on its own, it could when combined with other therapies [87]. Inhibiting the interaction of PD-1/PD-L1 with an antiPD-L1 antibody had the opposite effect and accelerated skin graft rejection [88]. However, diminishing PD-1 signaling in combination with anti-CD154 delayed islet rejection [89]. Apart from naïve $\mathrm{T}$ cell interactions, memory $\mathrm{T}$ cells also play a role in allograft rejection. Zhang et al. showed that sequestering alloreactive memory $\mathrm{CD}^{+} \mathrm{T}$ cells improved graft survival in a heart transplantation model [90], and CD4 $4^{+}$T cell subsets were involved. The Th1 subset was thought to be the most important $\mathrm{T}$ helper cell in transplantation by promoting the generation of cytotoxic cells, the activation of APCs and antibody production $[91,92]$, while the Th2 subset was seen as a regulatory cell in this model [93]. With the discovery of new T helper cell subsets, including Th17 (produces IL-17 and is associated with inflammatory disorders [94]) and Tregs, this paradigm has been revised: Th17 cells are now recognized as promoting graft rejection along with Th1 cells [93,94]. In humans, IL-23, a cytokine that induces Th17 differentiation, and IL-17 are elevated in the serum from patients who have had hepatic rejection [95]. IL-17 was also increased in the bronchoalveolar lavage of lung transplant patients with acute rejection [96] as well as in the urine of patients with subclinical kidney rejection [97]. Several mouse models have confirmed that IL-17 favors allograft rejection $[98,99]$. With the discovery of Tregs, the Th2 subset has lost its role as a protector cell in several models, allowing this new regulatory subset to take its place $[100,101]$.

These works summarize the importance of APC-T cell interactions against the foreign graft and how important it is to control their cross-talk following transplantation.

\section{The classical and new concepts of carbon monoxide}

The well-known odorless, colorless and tasteless gas carbon monoxide (CO) was originally described to bind hemoglobin with 140 times greater affinity than oxygen $\left(\mathrm{O}_{2}\right)$ by Haldane in 1895 [102], when it was classified as a cumulative poison. It is currently known that this affinity is approximately 210-250 times greater than $\mathrm{O}_{2}$. In 1906, Nasmith and Graham [103] confirmed the poisonous character of $\mathrm{CO}$, showing that this gas prevented $\mathrm{O}_{2}$ from reaching tissues. However, they also showed an increase in erythrocytes in the presence of elevated $\mathrm{CO}$ levels, similar to those found at high altitudes. This indicated that the body could stand higher levels of $\mathrm{CO}$ in certain situations and not succumb to it. The authors did not emphasize this discovery, and $\mathrm{CO}$ continued to be popularly associated as a villain for many years.

In 1952, Sjöstrand proved that CO was present in our body and that hemoglobin decomposition could produce CO [104]. Furthermore, increased heme levels were found to increase endogenous $\mathrm{CO}$ production [105]. It was only in 1968 that Tenhunen et al. showed a connection between heme oxygenase (HO) and $\mathrm{CO}$ [106]. They provided evidence that $\mathrm{CO}$ and bilirubin were by-products of the HO-mediated cleavage of heme [106,107]. CO was also shown to be produced by other mechanisms, including phenol oxidation $[108,109]$, the hormone progesterone [110] and the peroxidation of microsomal lipids and phospholipids [111-113]. Nevertheless, the majority of CO production in the body is dependent on $\mathrm{HO}$ activation [114].

$\mathrm{HO}$ is an enzyme that can open the heme ring in the presence of $\mathrm{O}_{2}$, nicotinamide adenine dinucleotide phosphate NADPH and (NADPH)-cytochrome 4450 reductase, thus cleaving heme into biliverdin, iron and $\mathrm{CO}$ $[115,116]$. The first isoform of HO-1 was described as inducible in 1974 [117,118], while the other two isoforms (HO-2 and $\mathrm{HO}-3$ ) were found to be constitutive $[119,120]$. HO-1 (32 kDa) is localized to microsomes and is induced in mammalian tissues, while HO-2 (36 kDa) is present in mitochondria and is expressed in the brain, 
testes, endothelium, kidney, liver and gastrointestinal tract [121]. HO-3 was found to be a pseudogene derived from the HO-2 gene [122].

HO-1, also known as heat shock protein 32 , has been extensively studied for its protective role. It was shown to have anti-proliferative [123], anti-apoptotic [124], anti-oxidant [125] and anti-inflammatory [126] effects.

HO-2 [127] and HO-1 [128,129] knockout mice broadened our knowledge of $\mathrm{HO}$ and its by-products, and they confirmed its anti-inflammatory role through their spontaneous development of an inflammatory phenotype. Two years later, the first case of HO-1 deficiency in humans was described. HO-1-deficient people share similarities with HO-1 knockout mice, as they display tissue iron deposition, lymphadenopathy, leukocytosis and sensitivity to oxidative stress injuries [130].

The discovery of HO-1 as a potential mechanism of immune therapy, and the connection of this enzyme to $\mathrm{CO}$ production, raised new ideas about this gas and implicated it as a novel therapy.

After a long absence of $\mathrm{CO}$ studies, physiological studies demonstrated that $\mathrm{CO}$ was a neurotransmitter in 1993 [131]. With this new vision and with the discoveries of other gases [132], CO began to be investigated as a potential therapy.

Studies concerning the mechanism of action of $\mathrm{CO}$ have shown that it binds to the heme moiety of soluble guanylyl cyclase (sGC), leading to cyclic guanosine monophosphate (cGMP) activation [133,134]. CO-induced cGMP is involved in vascular relaxation [133,134], the inhibition of vascular smooth cell proliferation $[135,136]$, the inhibition of platelet aggregation [137] and anti-apoptotic action on pancreatic $\beta$ cells [138]. The anti-apoptotic properties of $\mathrm{CO}$ have been extensively studied because of their possible indication of $\mathrm{CO}$ as a therapeutic agent for several disorders. $\mathrm{CO}$ was shown to prevent mitochondrial permeabilization, inhibiting the intrinsic apoptotic pathway [139]. In macrophage lineages, CO inhibited cytochrome $\mathrm{c}$ oxidase and the generation of mitochondrial ROS [140]. In astrocytes, CO was shown to induce cytochrome c oxidase activity and increased Bcl-2 expression, which rapidly interacted with cytochrome c oxidase to prevent apoptosis [141]. Endothelial cells require activation of the $\mathrm{p} 38 /$ mitogen-activated protein kinase (MAPK) pathway by CO to prevent TNF-induced cell death [142]. In contrast, CO promotes Fas/CD95-induced cell death by inhibiting activation of the ERK/MAPK pathway in $\mathrm{T}$ cells [143].

Although $\mathrm{CO}$ activates cGMP, nitric oxide (NO) activates it more potently [144]. The relationship between these two molecules seems to involve a complex negative feedback loop: $\mathrm{NO}$ induces $\mathrm{HO}-1$ expression and consequently $\mathrm{CO}$ production [145], while conversely, HO-1 and CO inhibit NO synthesis activity $[146,147]$.
Several groups began developing ways to release $\mathrm{CO}$ in order to manipulate the quantity of gas. $\mathrm{CO}$ at $250 \mathrm{ppm}$ was shown to induce macrophage phagocytosis, and the same condition was described to be beneficial in many animal disease models [148]. In 2002, Chauveau et al. [149] used methylene chloride as a prodrug to induce $\mathrm{CO}$ release by hepatic enzyme catabolism. Because methylene chloride use is dependent on the condition of the liver, Motterlini et al. searched for new CO-releasing molecule (CORM) candidates [150]. They identified molecules based on heavy metals surrounded by carbonyl groups, such as iron pentacarbonyl [Fe(CO)5], dimanganese decacarbonyl [Mn2(CO)10] and tricarbonyldichlororuthenium (II) dimers $[\mathrm{Ru}(\mathrm{CO}) 3 \mathrm{Cl} 2]$ 2. All of the compounds could convert deoxymyoglobin to carbonmonoxymyoglobin, which indicates that $\mathrm{CO}$ has been released from the metal complexes. These molecules were able to attenuate coronary vasoconstriction ex vivo and reduce acute hypertension in vivo. The same results were observed after hemin treatment, which stimulates $\mathrm{CO}$ release through $\mathrm{HO}-1$ activation.

The use of these complexes was a great advance in $\mathrm{CO}$ research, but there were still problems for in vivo studies. The requirement of a steric ligand or light to dissociate $\mathrm{CO}$ from the complex and the difficulty of solubilizing compounds in dimethylsulphoxide (DMSO) demanded a search for new compounds. Clark et al. developed tricarbonylchloro(glycinato)ruthenium(II) ([Ru9CO)3Cl (glycinate)]), also known as CORM-3, with [Mn2(CO)10] renamed as CORM-1 and $[\mathrm{Ru}(\mathrm{CO}) 3 \mathrm{Cl} 2] 2$ as CORM-2 [151]. CORM-3 is a water-soluble compound that is able to release $\mathrm{CO}$ into physiological solutions without prior activation. It was shown to protect the heart from ischemia-reperfusion injury and from cardiac allograft rejection [151]. More recently, a new CORM was identified, known as sodium boranocarbonate $\mathrm{Na} 2$ [H3BCO2] and termed CORM-A1, which does not contain a transition metal and is water soluble. It releases $\mathrm{CO}$ at a slower rate when compared to others CORMS [152]. CORM-A1 was shown to have cerebroprotective effects $[153,154]$, vasodilatory effects in the kidney [155] and antithrombotic properties $[156,157]$. However, it is less effective than the metal CORMs in certain aspects (e.g., bactericidal) [158]. Although several models of CORMs have been developed, the residual transition metal is potentially toxic, and further studies are required before these molecules can be applied in the clinics.

Interestingly, the use of $\mathrm{CO}$ as a gas is in phase I human clinical trials, and a study has been completed whereby $250 \mathrm{ppm}$ of CO was inhaled by healthy volunteers (www. clinicaltrials.com). Other clinical trials with the use of $\mathrm{CO}$ inhalation are ongoing in the USA, including trials for pulmonary fibrosis, severe pulmonary hypertension and postoperative ileus following colon resection. The advances in 
the use of therapeutic CO reinforce the idea of using this gas in immune-dependent models, such as solid organ transplantation.

\section{Immunomodulatory effects of $\mathrm{CO}$}

In innate immunity, the induction of $\mathrm{HO}-1$ increases DAF expression, which decreases complement activity and, consequently, decreases vascular injury [159]. TLR activation through IFN- $\beta /$ JAK2/STAT-1/INOS/NO signaling was inhibited by the use of CORM-2, which consequently inhibited macrophage HMGB-1 release [160]. The same treatment induced tolerogenic DCs, which inhibited TLRs, maturation, pro-inflammatory cytokine secretion, proliferation of alloreactive $\mathrm{T}$ cells and IRF-3 expression, while maintaining IL-10 production [161]. Macrophages exposed to $\mathrm{CO}$ also displayed inhibition of TLR activation via impaired translocation to lipid rafts and suppressed reactive oxygen species (ROS) generation [162].

CORM-2 and CO exposure affects endothelial cell adhesion by diminishing ICAM-1 expression concurrently with reduced proinflammatory cytokine (TNF and IL$1 \beta)$ production $[142,163]$. Other proinflammatory cytokines were affected after exposure to CO, including IL-6 and IL-17, which were downregulated in pulmonary epithelial cells through the ERK1/2 MAPK pathway [164]. This pathway inhibited by $\mathrm{CO}$, also led to diminished IL-2 expression and inhibited T cell proliferation [165]. Decreases in portal venous resistance through the p38 MAPK pathway was observed when rat livers were subjected to CO [166]. This pathway was also associated with protection against oxidant-induced lung injury by CO [167].

The role of $\mathrm{CO}$ in NK cells is poorly understood, while another important cell of the innate immune response, neutrophils, was shown to have inhibited migration in the presence of CO [168].

Wegiel et al. summarized the effects of $\mathrm{CO}$ in different immune cells, and as previously mentioned, macrophages and DCs develop a tolerogenic phenotype upon CO treatment [169]. APCs are the major link between the innate and adaptive immune responses, and $\mathrm{CO}$ treated DCs were shown to express diminished $\mathrm{MHC}$ class II, leading to decreased APC-induced T cell proliferation and TNF and IFN- $\gamma$ production [170]. CO also inhibited the $\mathrm{CD}^{+} \mathrm{T}$ cell autoimmune response and cellular accumulation in the pancreas in diabetes model [171]. Beyond the indirect action of $\mathrm{CO}$ on $\mathrm{T}$ cells, this gas has the ability to act directly on $\mathrm{T}$ cells by inhibiting IL-2 production and blocking T cell proliferation [165].

These works corroborate the idea of using $\mathrm{CO}$ as an immunosuppressant during transplantation (Figure 2), which can interfere at different stages of the transplant process.

\section{$\mathrm{CO}$ in transplantation}

Different organ transplant models indicated a protective role of $\mathrm{CO}$ administration during transplantation (Table 1).

\section{Donor}

Several studies have demonstrated the relevance of HO-1/ $\mathrm{CO}$ expression in organ donors that favor graft tolerance. In an islet allograft model, CO blocked TLR4 upregulation, diminishing the inflammatory response and cytokineinduced apoptosis, which protected the graft from rejection [172]. In a fully mismatched model, donor mice received hemin, a protoporphyrin that induces $\mathrm{HO}-1$ expression, and their aortas were transplanted into non-treated mice. The neointimal area, the proliferation of endothelial cells and the production of IFN- $\gamma$ by $\mathrm{CD}^{+}$T cells were reduced. The use of CORM-3 mimicked the effect of hemin, demonstrating the importance of $\mathrm{CO}$ in this model [173]. Donors inhaling $\mathrm{CO}$ or cold ischemia with $\mathrm{CO}$ perfusion improved graft function, and this was associated with decreased apoptosis and increased viability of endothelial cells and cardiomyocites [174]. CO has also been suggested as a potential therapy for kidney transplantation. The induction of $\mathrm{CO}$ in the donor by oral administration of methylene chloride was able to prevent chronic rejection of rat renal allografts [175]. Donors treated with CORM-2 presented fewer lymphocytic infiltrates and reduced acute tubular necrosis in the graft [176]. This protection was most likely related to CORM-2-induced endothelial changes via a reduction in NADPH-dependent superoxide anion production, IkB degradation, and E-selectin and ICAM-1 expression [176].

\section{Graft}

The use of Cobalt protoporphyrin in rapamycin-induced renal dysfunction following ischemia-reperfusion injury increased HO-1 levels and eased acute renal injury [177]. Similar results were observed with the CO inhalation model. This protection was associated with the induction of hypoxia inducible factor- $1 \alpha$ (HIF-1 $\alpha)$ and less severe apoptosis [178]. Cold ischemia of the liver, intestine, vein and kidney grafts in the presence of $\mathrm{CO}$ induced graft protection [179-184] with increased recipient survival, which was associated with increased expression of vascular endothelial growth factor (VEGF) and HIF-1 $\alpha$, leading to decreased apoptosis $[180,181]$. CO exposure during cold ischemia decreased TNF, IL-6, COX-2 and ICAM-1 expression, which led to reduced inflammation and modulated apoptosis by the increased expression of the anti-apoptotic Bcl-2 and decreased expression of the pro-apoptotic Bax through the sGC/ cGMP pathway $[182,184]$. The use of CORMs is a promising therapy because it is a soluble method of treating organs and subjects. Kidney perfusion with CORM-3 led to improved renal function and diminished acute tubular 


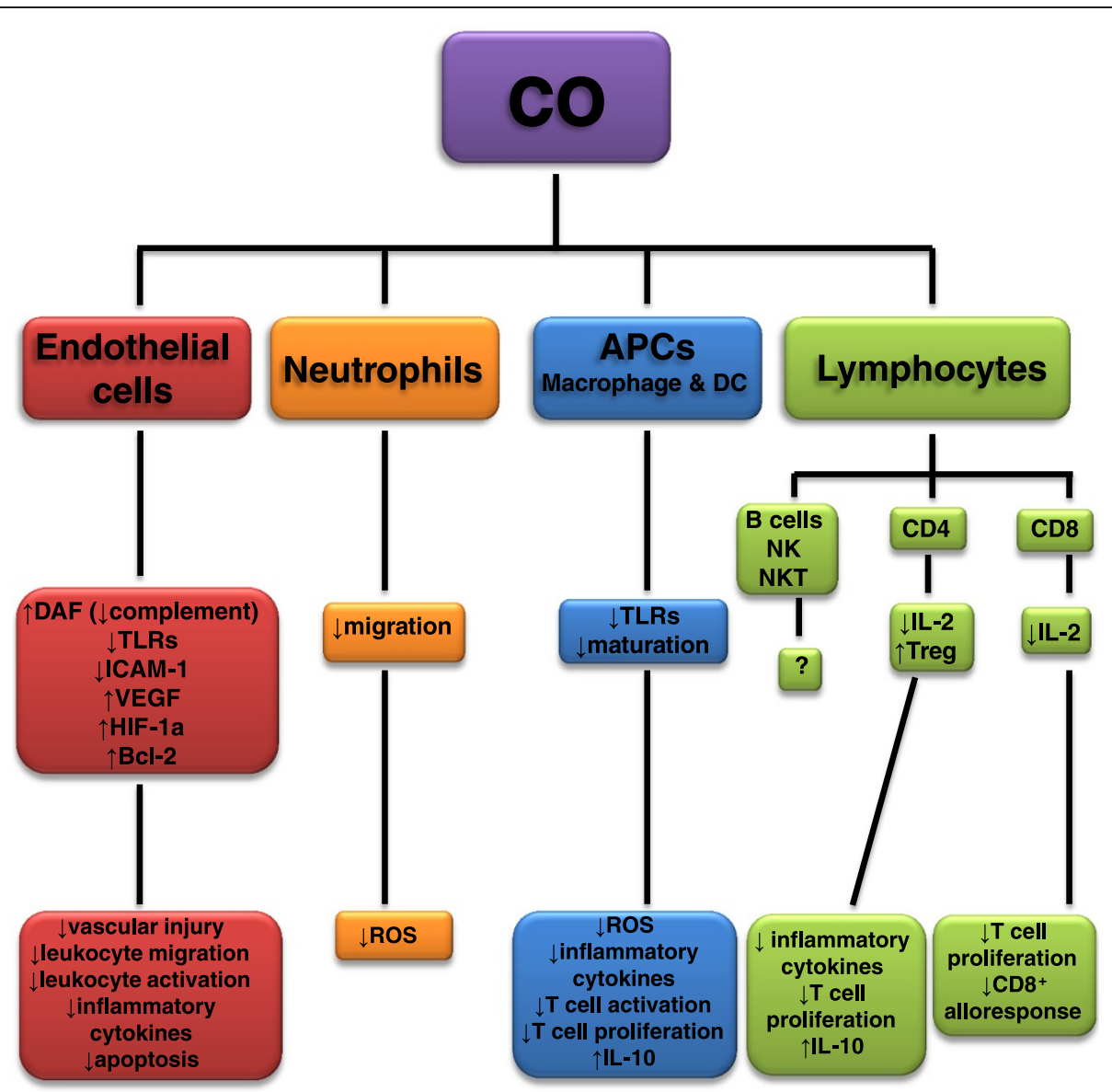

Figure 2 Immunomodulatory properties of carbon monoxide (CO). CO can act in different cells to downregulate the immune response. Endothelial cells have increased expression of decay accelerating factor (DAF), diminishing complement activation and vascular injury. These cells also have decreased Toll-like receptors (TLRs) and ICAM-1 expression in CO presence, which reduces leukocyte migration and activation, resulting in less inflammatory cytokines production. CO treatment increases vascular endothelial growth factor (VEGF), hypoxia-inducible factor (HIF)-1a and BCl-2 expression, which is associated to apoptosis decrease. Neutrophils are also affected by $\mathrm{CO}$, having impaired migration with diminished production of local reactive oxygen species (ROS). Antigen presenting cells (APCs) such as macrophages and dendritic cells (DC) have TLRs expression decreased after CO treatment, impairing their maturation leading to decreased ROS and inflammatory cytokines production, less T cell activation and proliferation and maintained IL-10 production. Although lymphocytes can be influenced by CO through APCS modulation, CO can directly act on lymphocytes by diminishing IL-2 production, which consequently suppresses T cell proliferation. CD4 ${ }^{+} \mathrm{T}$ cells are more prompt to develop Treg phenotype, which increases IL-10 production. $C D 8^{+} T$ cells have their alloresponse diminished when treated by $\mathrm{CO}$. The role of $\mathrm{CO}$ on B cells, NK and NKT cells activation remains unclear.

Table 1 Carbon monoxide effects on organ transplantation

\begin{tabular}{|c|c|c|}
\hline ORGAN & FINDINGS & REFERENCES \\
\hline Lung & $\downarrow$ apoptosis, $\downarrow$ inflammation, $\downarrow$ oxidation, $\uparrow$ tissue preservation & {$[194,201]$} \\
\hline Intestine & $\downarrow$ inflammation, $\uparrow$ graft survival, $\downarrow$ apoptosis & {$[182,195]$} \\
\hline Heart & $\begin{array}{l}\uparrow g r a f t \text { survival, } \uparrow \text { graft function, } \uparrow \text { tissue preservation, } \downarrow \text { ischemia/reperfusion injury, } \downarrow \text { cell proliferation, } \\
\downarrow \text { inflammation, } \downarrow \text { apoptosis, } \downarrow \text { cell infiltration, } \downarrow \text { cell activation, } \uparrow \text { Tregs }\end{array}$ & $\begin{array}{l}{[151,173,174,181,187,189,191,198} \\
200]\end{array}$ \\
\hline $\begin{array}{l}\text { Pancreatic } \\
\text { Islet }\end{array}$ & $\uparrow g r a f t$ survival, $\downarrow T L R 4$, $\downarrow$ inflammation, $\downarrow$ apoptosis & [172] \\
\hline Liver & $\uparrow$ tissue preservation, $\uparrow$ graft function, $\downarrow$ neutrophil accumulation, $\downarrow$ inflammation, $\downarrow$ apoptosis & {$[184,186,188,196,197]$} \\
\hline Kidney & $\begin{array}{l}\uparrow g r a f t \text { survival, } \uparrow g r a f t \text { function, } \downarrow \text { fibrosis, } \downarrow \text { ischemia/reperfusion injury, } \downarrow \text { apoptosis, } \downarrow \text { cell proliferation, } \\
\downarrow \text { inflammation, } \downarrow \text { cell infiltration }\end{array}$ & {$[175-180,185,192,193,202]$} \\
\hline
\end{tabular}


necrosis and glomerular necrosis [176]. In warm IR, CORM-3-treated animals were protected against acute kidney injury [185]. CORM-2 prevented hepatic IR injury by elevating Bcl-2 and inhibiting caspase 3, leading to decreased apoptosis and inhibiting the proinflammatory molecules NF-kB, TNF, IL-6 and ICAM-1 [186]. Isolated heart treatment with CORM-3 showed cadioprotection and improved myocardial function $[151,187]$. Similar results were observed in CORM-3-treated hepatic cold preservation [188]. In a rat model, CORM-3 improved aorta graft adventitial remodeling and neointima formation [189]. The combination of $\mathrm{CO}$ and biliverdin treatment for heart and kidney grafts resulted in protection against ischemia-reperfusion injury [190].

\section{Recipient}

Abdominal aortic transplants presented prolonged survival with CORM-2 treatment in a murine allograft model [191]. Kidney graft recipients exposed to CO after surgery displayed improved graft function and diminished ischemia-reperfusion injury [192]. In a chronic allograft nephropathy model, inhaled CO improved renal function with decreased tubular atrophy and decreased fibrosis. Impaired anti-donor IgG antibodies and decreased expression of macrophage inflammatory protein 1 (MIP-1a), chemokine receptors (CCR1, CXCR3, CXCR5), ICAM-1 and IL-2, leading to reduced $\mathrm{T}$ cell proliferation, were also observed [193]. In a lung transplant model, recipient animals were exposed to $\mathrm{CO}$ following surgery. As a result, a marked reduction in apoptosis, inflammation and tissue damage was observed in CO-subjected mice [194]. CO administration during small intestinal transplantation also reduced inflammation, with decreased levels of IL-6, IL$1 \beta$, iNOS and COX-2 in the graft and prolonged graft survival $[182,195]$. Recipients treated with CO gas presented improved graft function in a liver transplantation model due to the inhibition of proinflammatory molecules, such as TNF, ICAM-1 and iNOS, leading to decreased neutrophil accumulation and diminished necrosis [196]. Similar results were obtained when recipient rats were treated by methylene chloride in a liver transplant model; the recipients displayed increased survival, impaired CD95/FasLmediated apoptosis and preserved hepatic architecture and function [197].

In murine heart xenotransplantation, the transplanted heart with inhibited HO-1 was rapidly rejected from the recipient rat in comparison with the wild-type graft, suggesting the importance of HO-1 production by the graft. Nevertheless, treatment of both the donor and the recipient with $\mathrm{CO}$ prolonged the graft survival independently of HO-1 inhibition by blocking platelet aggregation and endothelial cell apoptosis [198]. Allogeneic transplanted aortic segments develop arteriosclerotic lesions. CO exposure was able to inhibit the hyperplasia associated with
Table 2 Carbon monoxide immunomodulation during transplantation

\begin{tabular}{|c|c|}
\hline $\begin{array}{l}\text { CO } \\
\text { TARGET }\end{array}$ & CONSEQUENCES \\
\hline \multirow[t]{8}{*}{ DONOR } & $\downarrow$ Toll-like receptor (TLR)4 \\
\hline & $\downarrow$ endothelial cell proliferation \\
\hline & \lymphocytic infiltration \\
\hline & $\downarrow$ inflammatory cytokines production (IFN-g) \\
\hline & $\downarrow$ apoptosis \\
\hline & $\downarrow$ Reactive oxygen species (ROS) \\
\hline & $\downarrow N F K B$ (IKB degradation) \\
\hline & $\downarrow$ E-selectin/ ICAM-1 \\
\hline \multirow[t]{7}{*}{ GRAFT } & $\uparrow$ Hypoxia inducible factor (HIF)-1a \\
\hline & $\uparrow$ Vascular endothelial growth factor (VEGF) \\
\hline & $\downarrow$ apoptosis ( $\uparrow$ Bcl-2, $\downarrow$ Bax, $\downarrow$ caspase 3 ) \\
\hline & $\downarrow$ \inflammatory cytokines production (TNF, IL-6) \\
\hline & $\downarrow$ prostaglandin (COX2) \\
\hline & $\downarrow$ ICAM-1 \\
\hline & $\downarrow N F K B$ \\
\hline \multirow[t]{17}{*}{ RECIPIENT } & $\downarrow \downarrow$ schemia and reperfusion injury \\
\hline & $\downarrow$ fibrosis \\
\hline & $\downarrow$ anti-donor lgG antibodies \\
\hline & $\downarrow$ chemokine receptors (CCR1, CXCR3, CXCR5) \\
\hline & $\downarrow$ dchemokines (IL-8, MIP-1a) \\
\hline & $\downarrow$ \CAM-1 \\
\hline & $\downarrow \| L-2$ ( $\downarrow T$ cell proliferation) \\
\hline & $\begin{array}{l}\text { \leukocyte infiltration (CD3+, CD4+, CD8+ T cells and } \\
\text { macrophages) }\end{array}$ \\
\hline & $\downarrow$ macrophage activation ( $\downarrow$ MHC class II) \\
\hline & $\downarrow$ neutrophil activation ( $\downarrow$ MPO) \\
\hline & $\downarrow$ apoptosis ( $\downarrow$ CD95/FasL) \\
\hline & $\downarrow$ inflammatory cytokines production (IL-1 $\beta$, TNF) \\
\hline & $\downarrow$ iNOS \\
\hline & $\downarrow$ prostaglandin (COX2) \\
\hline & $\downarrow$ platelet aggregation \\
\hline & 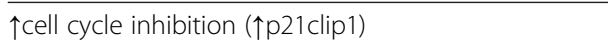 \\
\hline & 个Treg (Foxp3+ T cells) \\
\hline
\end{tabular}

chronic graft rejection with fewer graft infiltrating macrophages, $\mathrm{CD}^{+}, \mathrm{CD}^{+}$and $\mathrm{CD} 8^{+} \mathrm{T}$ cells. The macrophages were also less activated and presented diminished MHC class II and ICAM-1 expression. These effects were dependent on guanylate cyclase activation and cGMP generation via activation of the p38/MAPK pathway and expression of the cell cycle inhibitor p21 ${ }^{\text {clip1 }}$ [199]. In a heart allograft model, the combination of HO-1, CO and bilirubin treatments led to long-term survival and tolerance of the graft by inducing Foxp3+ Tregs [200]. In a rodent model of lung transplantation from deceased donors, the combination of $\mathrm{CO}$ gas and biliverdin treatment induced cytoprotection by attenuating MPO, IL- 8 and TNF in the 
graft and by oxidation, with low levels of malonaldhyde and superoxide dismutase [201].

More recently, Hanto et al. introduced the use of a device that can deliver $\mathrm{CO}$ by $\mathrm{mg} / \mathrm{kg}$, which is an advance for future therapeutic $\mathrm{CO}$ administration. They showed reduced DGF in a kidney allograft swine model [202].

Interventions with $\mathrm{CO}$ were efficient at different points of the transplant (Table 2). Summarizing these studies, $\mathrm{CO}$ appears to play an important role in controlling the immune response and graft acceptance. However, further investigation is required concerning the phenotypes of cells (DC, macrophages, $\mathrm{T}$ cells) after $\mathrm{CO}$ treatment during transplantation and to confirm the described tolerogenic effect of $\mathrm{CO}$ in different models. It would also be interesting to further analyze the dose of CORM and the resulting side-effects prior to starting use in humans. Nevertheless, $\mathrm{CO}$ is a good candidate for potential changes in the clinical setting.

\section{Conclusions}

Our current knowledge about $\mathrm{CO}$ completely disrupts the idea that it is only a dangerous gas. Instead, it shows that we are capable of manipulating it and can strategically use it for clinical purposes. In this review, we highlighted the protective properties of $\mathrm{CO}$ associated with its capacity to modulate the immune system. CO was shown to downregulate components and cells of the innate immune response, thereby impairing inflammation and the activation of the adaptive immune response. Moreover, $\mathrm{CO}$ was able to directly act on adaptive immune cells, which play a primary role in allograft rejection. Due to its capacity to immunomodulate the environment, this intervention was effective during the three stages of transplantation (donor, graft and recipient), widening the possibilities of its use. In conclusion, $\mathrm{CO}$ has the capacity to downmodulate the immune response, suggesting its use as an attractive therapeutic agent during transplantation.

\section{Abbreviations}

CO: Carbon monoxide; CORMs: Carbon monoxide releasing molecules; DGF: Delayed graft function; HO-1: Heme oxygenase-1; MAPK: Mitogen activated protein kinase; NO: Nitric oxide; IR: Ischemia and reperfusion.

\section{Competing interests}

The authors have no competing interests.

\section{Authors' contributions}

MA wrote the manuscript; NC wrote and corrected the manuscript. Both authors read and approved the final manuscript.

\section{Authors' information}

MA - Postdoctoral research fellow at the Laboratory of Transplantation Immunobiology, Institute of Biomedical Sciences, University of Sao Paulo, Brazil.

NC - Professor and Head of the Department of Immunology, Institute of Biomedical Sciences, University of Sao Paulo, Brazil.

\section{Acknowledgements}

This work was supported by CNPq (CNPq/Inserm, INCT Complex Fluids, MCT/ CNPq/FINEP 559887/2010-8 PNPD 159018/2011-0) and FAPESP (12/02270-2).

Received: 4 September 2012 Accepted: 31 December 2012

Published: 7 January 2013

\section{References}

1. Briganti EM, Russ GR, McNeil JJ, Atkins RC, Chadban SJ: Risk of renal allograft loss from recurrent glomerulonephritis. N Engl J Med 2002, 347:103-109.

2. Chapman JR, O'Connell PJ, Nankivell BJ: Chronic renal allograft dysfunction. J Am Soc Nephrol 2005, 16:3015-3026.

3. Binet I, Nickeleit V, Hirsch HH, Prince O, Dalquen P, Gudat F, Mihatsch MJ, Thiel G: Polyomavirus disease under new immunosuppressive drugs: a cause of renal graft dysfunction and graft loss. Transplantation 1999, 67:918-922

4. Perico N, Cattaneo D, Sayegh MH, Remuzzi G: Delayed graft function in kidney transplantation. Lancet 2004, 364:1814-1827.

5. Arslan F, Keogh B, McGuirk P, Parker AE: TLR2 and TLR4 in ischemia reperfusion injury. Mediators Inflamm 2010, 2010:704202.

6. Devarajan P: Update on mechanisms of ischemic acute kidney injury. J Am Soc Nephrol 2006, 17:1503-1520.

7. Hosgood SA, Bagul A, Yang B, Nicholson ML: The relative effects of warm and cold ischemic injury in an experimental model of nonheartbeating donor kidneys. Transplantation 2008, 85:88-92.

8. Varotti G, Grazi GL, Vetrone G, Ercolani G, Cescon M, Del Gaudio M, Ravaioli M, Cavallari A, Pinna A: Causes of early acute graft failure after liver transplantation: analysis of a 17-year single-centre experience. Clin Transplant 2005, 19:492-500.

9. Clavien PA, Harvey PR, Strasberg SM: Preservation and reperfusion injuries in liver allografts. An overview and synthesis of current studies. Transplantation 1992, 53:957-978.

10. Sacks SH, Zhou W: The role of complement in the early immune response to transplantation. Nat Rev Immunol 2012, 12:431-442.

11. Welbourn R, Goldman G, Kobzik L, Paterson IS, Valeri CR, Shepro D, Hechtman HB: Role of neutrophil adherence receptors (CD 18) in lung permeability following lower torso ischemia. Circ Res 1992, 71:82-86.

12. de Vries $B$, Kohl J, Leclercq WK, Wolfs TG, van Bijnen AA, Heeringa P, Buurman WA: Complement factor C5a mediates renal ischemiareperfusion injury independent from neutrophils. J Immunol 2003, 170:3883-3889.

13. Lewis $A G$, Kohl G, Ma Q, Devarajan P, Kohl J: Pharmacological targeting of C5a receptors during organ preservation improves kidney graft survival. Clin Exp Immunol 2008, 153:117-126.

14. Qiu W, Zhang Y, Liu X, Zhou J, Li Y, Zhou Y, Shan K, Xia M, Che N, Feng X, et al: Sublytic C5b-9 complexes induce proliferative changes of glomerular mesangial cells in rat Thy-1 nephritis through TRAF6mediated PI3K-dependent Akt1 activation. J Pathol 2012, 226:619-632.

15. Biancone L, David S, Della Pietra V, Montrucchio G, Cambi V, Camussi G: Alternative pathway activation of complement by cultured human proximal tubular epithelial cells. Kidney Int 1994, 45:451-460.

16. David S, Biancone L, Caserta C, Bussolati B, Cambi V, Camussi G: Alternative pathway complement activation induces proinflammatory activity in human proximal tubular epithelial cells. Nephrol Dial Transplant 1997, 12:51-56.

17. Tedesco F, Pausa M, Nardon E, Introna M, Mantovani A, Dobrina A: The cytolytically inactive terminal complement complex activates endothelial cells to express adhesion molecules and tissue factor procoagulant activity. J Exp Med 1997, 185:1619-1627.

18. Fondevila C, Shen XD, Tsuchihashi S, Uchida Y, Freitas MC, Ke B, Busuttil RW, Kupiec-Weglinski JW: The membrane attack complex (C5b-9) in liver cold ischemia and reperfusion injury. Liver Transp/ 2008, 14:1133-1141.

19. de Vries B, Walter SJ, Peutz-Kootstra CJ, Wolfs TG, van Heurn LW, Buurman WA: The mannose-binding lectin-pathway is involved in complement activation in the course of renal ischemia-reperfusion injury. Am J Pathol 2004, 165:1677-1688.

20. Thurman JM, Ljubanovic D, Royer PA, Kraus DM, Molina H, Barry NP, Proctor G, Levi M, Holers VM: Altered renal tubular expression of the complement 
inhibitor Crry permits complement activation after ischemia/reperfusion. J Clin Invest 2006, 116:357-368.

21. Zhao P, Wang J, He L, Ma H, Zhang X, Zhu X, Dolence EK, Ren J, Li J: Deficiency in TLR4 signal transduction ameliorates cardiac injury and cardiomyocyte contractile dysfunction during ischemia. J Cell Mol Med 2009, 13:1513-1525.

22. Favre J, Musette P, Douin-Echinard V, Laude K, Henry JP, Arnal JF, Thuillez C, Richard V: Toll-like receptors 2-deficient mice are protected against postischemic coronary endothelial dysfunction. Arterioscler Thromb Vasc Biol 2007, 27:1064-1071.

23. Zhang J, Wu H, Wang L, Zhang J, Wang $H$, Zheng Q: TLR2 mRNA upregulation in ischemic lobes in mouse partial hepatic ischemia/reperfusion injury model. J Huazhong Univ Sci Technolog Med Sci 2004, 24:144-146.

24. Shen XD, Ke B, Zhai Y, Gao F, Busuttil RW, Cheng G, Kupiec-Weglinski JW: Toll-like receptor and heme oxygenase-1 signaling in hepatic ischemia/ reperfusion injury. Am J Transplant 2005, 5:1793-1800.

25. Leemans JC, Stokman G, Claessen N, Rouschop KM, Teske GJ, Kirschning CJ, Akira S, van der Poll T, Weening JJ, Florquin S: Renal-associated TLR2 mediates ischemia/reperfusion injury in the kidney. $J$ Clin Invest 2005, 115:2894-2903.

26. Shigeoka AA, Holscher TD, King AJ, Hall FW, Kiosses WB, Tobias PS, Mackman N, McKay DB: TLR2 is constitutively expressed within the kidney and participates in ischemic renal injury through both MyD88dependent and -independent pathways. J Immunol 2007, 178:6252-6258.

27. Wu H, Chen G, Wyburn KR, Yin J, Bertolino P, Eris JM, Alexander SI, Sharland AF, Chadban SJ: TLR4 activation mediates kidney ischemia/reperfusion injury. J Clin Invest 2007, 117:2847-2859.

28. Pulskens WP. Teske GJ, Butter LM, Roelofs JJ, van der Poll T, Florquin S, Leemans JC: Toll-like receptor-4 coordinates the innate immune response of the kidney to renal ischemia/reperfusion injury. PLoS One 2008, 3:e3596.

29. Rabb HA: Cell adhesion molecules and the kidney. Am J Kidney Dis 1994, 23:155-166

30. Brady HR: Leukocyte adhesion molecules and kidney diseases. Kidney Int 1994, 45:1285-1300.

31. Springer TA: Adhesion receptors of the immune system. Nature 1990, 346:425-434.

32. Lasky LA: Selectins: interpreters of cell-specific carbohydrate information during inflammation. Science 1992, 258:964-969.

33. Winn RK, Mihelicic D, Vedder NB, Sharar SR, Harlan JM: Monoclonal antibodies to leukocyte and endothelial adhesion molecules attenuate ischemia-reperfusion injury. Behring Inst Mitt 1993, :229-237.

34. Rabb H, Mendiola CC, Dietz J, Saba SR, Issekutz TB, Abanilla F, Bonventre JV, Ramirez G: Role of CD11a and CD11b in ischemic acute renal failure in rats. Am J Physiol 1994, 267:F1052-1058.

35. Kelly KJ, Williams WW Jr, Colvin RB, Meehan SM, Springer TA, Gutierrez-Ramos $J C$, Bonventre JV: Intercellular adhesion molecule-1-deficient mice are protected against ischemic renal injury. J Clin Invest 1996, 97:1056-1063

36. Rabb H, Ramirez G, Saba SR, Reynolds D, Xu J, Flavell R, Antonia S: Renal ischemic-reperfusion injury in L-selectin-deficient mice. Am J Physiol 1996, 271:F408-413

37. Li L, Huang L, Sung SS, Lobo PI, Brown MG, Gregg RK, Engelhard VH, Okusa MD: NKT cell activation mediates neutrophil IFN-gamma production and renal ischemia-reperfusion injury. J Immunol 2007, 178:5899-5911.

38. Li L, Huang L, Vergis AL, Ye H, Bajwa A, Narayan V, Strieter RM, Rosin DL, Okusa MD: IL-17 produced by neutrophils regulates IFN-gammamediated neutrophil migration in mouse kidney ischemia-reperfusion injury. J Clin Invest 2010, 120:331-342.

39. Lappas CM, Day YJ, Marshall MA, Engelhard VH, Linden J: Adenosine A2A receptor activation reduces hepatic ischemia reperfusion injury by inhibiting CD1d-dependent NKT cell activation. J Exp Med 2006, 203:2639-2648.

40. Sharma AK, LaPar DJ, Zhao Y, Li L, Lau CL, Kron IL, Iwakura Y, Okusa MD, Laubach VE: Natural killer T cell-derived IL-17 mediates lung ischemiareperfusion injury. Am J Respir Crit Care Med 2011, 183:1539-1549.

41. Li L, Huang L, Sung SS, Vergis AL, Rosin DL, Rose CE Jr, Lobo PI, Okusa MD: The chemokine receptors CCR2 and CX3CR1 mediate monocyte/ macrophage trafficking in kidney ischemia-reperfusion injury. Kidney Int 2008, 74:1526-1537.
42. Day YJ, Huang L, Ye H, Linden J, Okusa MD: Renal ischemia-reperfusion injury and adenosine $2 \mathrm{~A}$ receptor-mediated tissue protection: role of macrophages. Am J Physiol Renal Physiol 2005, 288:F722-731.

43. Ferenbach DA, Sheldrake TA, Dhaliwal K, Kipari TM, Marson LP, Kluth DC, Hughes J: Macrophage/monocyte depletion by clodronate, but not diphtheria toxin, improves renal ischemia/reperfusion injury in mice. Kidney Int 2012, 82:928-933.

44. Chandraker A, Takada M, Nadeau KC, Peach R, Tilney NL, Sayegh MH: CD28-b7 blockade in organ dysfunction secondary to cold ischemia/ reperfusion injury. Kidney Int 1997, 52:1678-1684.

45. Dong X, Swaminathan S, Bachman LA, Croatt AJ, Nath KA, Griffin MD: Antigen presentation by dendritic cells in renal lymph nodes is linked to systemic and local injury to the kidney. Kidney Int 2005, 68:1096-1108.

46. Dong X, Swaminathan S, Bachman LA, Croatt AJ, Nath KA, Griffin MD: Resident dendritic cells are the predominant TNF-secreting cell in early renal ischemia-reperfusion injury. Kidney Int 2007, 71:619-628.

47. Zhang M, Michael LH, Grosjean SA, Kelly RA, Carroll MC, Entman ML: The role of natural IgM in myocardial ischemia-reperfusion injury. $J \mathrm{Mol}$ Cell Cardiol 2006, 41:62-67.

48. Chan RK, Verna N, Afnan J, Zhang M, Ibrahim S, Carroll MC, Moore FD Jr: Attenuation of skeletal muscle reperfusion injury with intravenous 12 amino acid peptides that bind to pathogenic lgM. Surgeny 2006, 139:236-243.

49. Zhang M, Austen WG Jr, Chiu I, Alicot EM, Hung R, Ma M, Verna N, Xu M, Hechtman HB, Moore FD Jr, Carroll MC: Identification of a specific selfreactive IgM antibody that initiates intestinal ischemia/reperfusion injury. Proc Natl Acad Sci USA 2004, 101:3886-3891.

50. Burne-Taney MJ, Ascon DB, Daniels F, Racusen L, Baldwin W, Rabb H: B cell deficiency confers protection from renal ischemia reperfusion injury. $\mathrm{J}$ Immunol 2003, 171:3210-3215.

51. Austen WG Jr, Zhang M, Chan R, Friend D, Hechtman HB, Carroll MC, Moore FD Jr: Murine hindlimb reperfusion injury can be initiated by a selfreactive monoclonal lgM. Surgery 2004, 136:401-406.

52. Burne-Taney MJ, Yokota-lkeda N, Rabb H: Effects of combined T- and B-cell deficiency on murine ischemia reperfusion injury. Am J Transplant 2005, 5:1186-1193.

53. Martin M, Mory C, Prescher A, Wittekind C, Fiedler M, Uhlmann D: Protective effects of early CD4(+) T cell reduction in hepatic ischemia/ reperfusion injury. J Gastrointest Surg 2010, 14:511-519.

54. Yang Z, Sharma AK, Linden J, Kron IL, Laubach VE: CD4+ T lymphocytes mediate acute pulmonary ischemia-reperfusion injury. J Thorac Cardiovasc Surg 2009, 137:695-702. discussion 702.

55. Shigematsu T, Wolf RE, Granger DN: T-lymphocytes modulate the microvascular and inflammatory responses to intestinal ischemiareperfusion. Microcirculation 2002, 9:99-109.

56. Pinheiro HS, Camara NO, Noronha IL, Maugeri IL, Franco MF, Medina JO, Pacheco-Silva A: Contribution of CD4+ T cells to the early mechanisms of ischemia- reperfusion injury in a mouse model of acute renal failure. Braz J Med Biol Res 2007, 40:557-568.

57. Burne MJ, Daniels F, El Ghandour A, Mauiyyedi S, Colvin RB, O'Donnell MP, Rabb H: Identification of the CD4(+) T cell as a major pathogenic factor in ischemic acute renal failure. J Clin Invest 2001, 108:1283-1290.

58. Zwacka RM, Zhang Y, Halldorson J, Schlossberg H, Dudus L, Engelhardt JF: CD4(+) T-lymphocytes mediate ischemia/reperfusion-induced inflammatory responses in mouse liver. J Clin Invest 1997, 100:279-289.

59. Shackleton $C R$, Ettinger SL, McLoughlin MG, Scudamore $C H$, Miller RR, Keown PA: Effect of recovery from ischemic injury on class I and class II MHC antigen expression. Transplantation 1990, 49:641-644.

60. Satpute SR, Park JM, Jang HR, Agreda P, Liu M, Gandolfo MT, Racusen L, Rabb H: The role for T cell repertoire/antigen-specific interactions in experimental kidney ischemia reperfusion injury. J Immunol 2009, 183:984-992.

61. Bromberg JS, Heeger PS, Li XC: Evolving paradigms that determine the fate of an allograft. Am J Transplant 2010, 10:1143-1148.

62. Damman J, Seelen MA, Moers C, Daha MR, Rahmel A, Leuvenink HG, Paul A, Pirenne J, Ploeg RJ: Systemic complement activation in deceased donors is associated with acute rejection after renal transplantation in the recipient. Transplantation 2011, 92:163-169.

63. Muller TF, Kraus M, Neumann C, Lange H: Detection of renal allograft rejection by complement components C5A and TCC in plasma and urine. J Lab Clin Med 1997, 129:62-71. 
64. Welch TR, Beischel LS, Witte DP: Differential expression of complement C3 and C4 in the human kidney. J Clin Invest 1993, 92:1451-1458.

65. Andrews PA, Finn JE, Mathieson PW, Sacks SH: Molecular analysis of C3 allotypes related to transplant outcome in human renal allografts. Transplantation 1995, 60:1342-1346.

66. Pratt JR, Basheer SA, Sacks SH: Local synthesis of complement component C3 regulates acute renal transplant rejection. Nat Med 2002, 8:582-587.

67. Fildes JE, Shaw SM, Walker AH, McAlindon M, Williams SG, Keevil BG, Yonan $\mathrm{N}$ : Mannose-binding lectin deficiency offers protection from acute graft rejection after heart transplantation. J Heart Lung Transplant 2008, 27:1353-1356

68. Pavlov V, Raedler H, Yuan S, Leisman S, Kwan WH, Lalli PN, Medof ME, Heeger PS: Donor deficiency of decay-accelerating factor accelerates murine T cell-mediated cardiac allograft rejection. J Immunol 2008, 181:4580-4589.

69. Wang S, Schmaderer C, Kiss E, Schmidt C, Bonrouhi M, Porubsky S, Gretz N, Schaefer L, Kirschning CJ, Popovic ZV, Grone HJ: Recipient Toll-like receptors contribute to chronic graft dysfunction by both MyD88- and TRIF-dependent signaling. Dis Model Mech 2010, 3:92-103.

70. Jiang J, Arp J, Kubelik D, Zassoko R, Liu W, Wise Y, Macaulay C, Garcia B, McFadden G, Lucas AR, Wang H: Induction of indefinite cardiac allograft survival correlates with toll-like receptor 2 and 4 downregulation after serine protease inhibitor-1 (Serp-1) treatment. Transplantation 2007, 84:1158-1167.

71. Methe H, Zimmer E, Grimm C, Nabauer M, Koglin J: Evidence for a role of toll-like receptor 4 in development of chronic allograft rejection after cardiac transplantation. Transplantation 2004, 78:1324-1331.

72. Kruger B, Krick S, Dhillon N, Lerner SM, Ames S, Bromberg JS, Lin M, Walsh $L$, Vella J, Fischereder $M$, et al: Donor Toll-like receptor 4 contributes to ischemia and reperfusion injury following human kidney transplantation. Proc Natl Acad Sci USA 2009, 106:3390-3395.

73. Jiang W, Hu M, Rao J, Xu X, Wang X, Kong L: Over-expression of Toll-like receptors and their ligands in small-for-size graft. Hepatol Res 2010, 40:318-329.

74. Deng JF, Geng L, Qian YG, Li H, Wang Y, Xie HY, Feng XW, Zheng SS: The role of toll-like receptors 2 and 4 in acute allograft rejection after liver transplantation. Transplant Proc 2007, 39:3222-3224.

75. Feng L, Ke N, Ye Z, Guo Y, Li S, Li Q, Li Y: Expression of NKG2D and its ligand in mouse heart allografts may have a role in acute rejection. Transplant Proc 2009, 41:4332-4339.

76. Beilke JN, Kuhl NR, Van Kaer L, Gill RG: NK cells promote islet allograft tolerance via a perforin-dependent mechanism. Nat Med 2005, 11:1059-1065.

77. Yu G, Xu X, Vu MD, Kilpatrick ED, Li XC: NK cells promote transplant tolerance by killing donor antigen-presenting cells. J Exp Med 2006 203:1851-1858.

78. Krieger NR, Yin DP, Fathman CG: CD4+ but not CD8+ cells are essential for allorejection. J Exp Med 1996, 184:2013-2018.

79. Smyth MJ: Fas ligand-mediated bystander lysis of syngeneic cells in response to an allogeneic stimulus. J Immunol 1997, 158:5765-5772.

80. Valujskikh A, Baldwin WM 3rd, Fairchild RL: Recent progress and new perspectives in studying $T$ cell responses to allografts. Am J Transplant 2010, 10:1117-1125

81. Lenschow DJ, Walunas TL, Bluestone JA: CD28/B7 system of T cell costimulation. Annu Rev Immunol 1996, 14:233-258.

82. Kosuge H, Suzuki J, Gotoh R, Koga N, Ito H, Isobe M, Inobe M, Uede T: Induction of immunologic tolerance to cardiac allograft by simultaneous blockade of inducible co-stimulator and cytotoxic T-lymphocyte antigen 4 pathway. Transplantation 2003, 75:1374-1379.

83. Nakamura $Y$, Yasunami $Y$, Satoh M, Hirakawa E, Katsuta H, Ono J, Kamada M, Todo S, Nakayama T, Taniguchi M, Ikeda S: Acceptance of islet allografts in the liver of mice by blockade of an inducible costimulator. Transplantation 2003, 75:1115-1118.

84. Nanji SA, Hancock WW, Anderson CC, Adams AB, Luo B, Schur CD, Pawlick RL, Wang L, Coyle AJ, Larsen CP, Shapiro AM: Multiple combination therapies involving blockade of ICOS/B7RP-1 costimulation facilitate long-term islet allograft survival. Am J Transplant 2004, 4:526-536.

85. Ozkaynak E, Gao W, Shemmeri N, Wang C, Gutierrez-Ramos JC, Amaral J, Qin S, Rottman JB, Coyle AJ, Hancock WW: Importance of ICOS-B7RP-1 costimulation in acute and chronic allograft rejection. Nat Immunol 2001, 2:591-596.
86. Harada H, Salama AD, Sho M, Izawa A, Sandner SE, Ito T, Akiba H, Yagita H, Sharpe AH, Freeman GJ, Sayegh MH: The role of the ICOS-B7h T cell costimulatory pathway in transplantation immunity. J Clin Invest 2003, 112:234-243.

87. Yuan X, Salama AD, Dong V, Schmitt I, Najafian N, Chandraker A, Akiba H, Yagita $H$, Sayegh $M H$ : The role of the CD134-CD134 ligand costimulatory pathway in alloimmune responses in vivo. J Immunol 2003, 170:2949-2955

88. Sandner SE, Clarkson MR, Salama AD, Sanchez-Fueyo A, Domenig C, Habicht A, Najafian N, Yagita H, Azuma M, Turka LA, Sayegh MH: Role of the programmed death-1 pathway in regulation of alloimmune responses in vivo. J Immunol 2005, 174:3408-3415.

89. Gao W, Demirci G, Strom TB, Li XC: Stimulating PD-1-negative signals concurrent with blocking CD154 co-stimulation induces long-term islet allograft survival. Transplantation 2003, 76:994-999.

90. Zhang Q, Chen Y, Fairchild RL, Heeger PS, Valujskikh A: Lymphoid sequestration of alloreactive memory CD4 T cells promotes cardiac allograft survival. J Immunol 2006, 176:770-777.

91. Dallman MJ: Cytokines and transplantation: Th1/Th2 regulation of the immune response to solid organ transplants in the adult. Curr Opin Immunol 1995, 7:632-638.

92. Sayegh MH, Akalin E, Hancock WW, Russell ME, Carpenter CB, Linsley PS, Turka LA: CD28-B7 blockade after alloantigenic challenge in vivo inhibits Th1 cytokines but spares Th2. J Exp Med 1995, 181:1869-1874.

93. Atalar K, Afzali B, Lord G, Lombardi G: Relative roles of Th1 and Th17 effector cells in allograft rejection. Curr Opin Organ Transplant 2009, 14:23-29.

94. Afzali B, Lombardi G, Lechler Rl, Lord GM: The role of T helper 17 (Th17) and regulatory $T$ cells (Treg) in human organ transplantation and autoimmune disease. Clin Exp Immunol 2007, 148:32-46.

95. Fabrega E, Lopez-Hoyos M, San Segundo D, Casafont F, Pons-Romero F: Changes in the serum levels of interleukin-17/interleukin-23 during acute rejection in liver transplantation. Liver Transp/ 2009, 15:629-633.

96. Vanaudenaerde BM, Dupont LJ, Wuyts WA, Verbeken EK, Meyts I, Bullens DM, Dilissen E, Luyts L, Van Raemdonck DE, Verleden GM: The role of interleukin-17 during acute rejection after lung transplantation. Eur Respir J 2006, 27:779-787.

97. Loong CC, Hsieh HG, Lui WY, Chen A, Lin CY: Evidence for the early involvement of interleukin 17 in human and experimental renal allograft rejection. J Pathol 2002, 197:322-332.

98. Burrell BE, Bishop DK: Th17 cells and transplant acceptance. Transplantation 2010, 90:945-948.

99. Heidt S, Segundo DS, Chadha R, Wood KJ: The impact of Th17 cells on transplant rejection and the induction of tolerance. Curr Opin Organ Transplant 2010, 15:456-461.

100. Wood KJ, Bushell A, Hester J: Regulatory immune cells in transplantation. Nat Rev Immunol 2012, 12:417-430.

101. Strom TB, Koulmanda M: Recently discovered T cell subsets cannot keep their commitments. J Am Soc Nephrol 2009, 20:1677-1680.

102. Haldane J: The Action of Carbonic Oxide on Man. J Physiol 1895, 18:430-462.

103. Nasmith GG, Graham DA: The haematology of carbon-monoxide poisoning. J Physiol 1906, 35:32-52.

104. Sjostrand T: The formation of carbon monoxide by the decomposition of haemoglobin in vivo. Acta Physio/ Scand 1952, 26:338-344.

105. Coburn RF, Williams WJ, Kahn SB: Endogenous carbon monoxide production in patients with hemolytic anemia. J Clin Invest 1966, 45:460-468.

106. Tenhunen R, Marver HS, Schmid R: The enzymatic conversion of heme to bilirubin by microsomal heme oxygenase. Proc Natl Acad Sci USA 1968 $61: 748-755$

107. Tenhunen R, Marver HS, Schmid R: Microsomal heme oxygenase. Characterization of the enzyme. J Biol Chem 1969, 244:6388-6394

108. Coburn RF: Enhancement by phenobarbital and diphenylhydantoin of carbon monoxide production in normal man. N Engl J Med 1970, 283:512-515.

109. Miyahara S, Takahashi H: Biological CO evolution. Carbon monoxide evolution during auto- and enzymatic oxidation of phenols. J Biochem 1971, 69:231-233.

110. Delivoria-Papadopoulos M, Coburn RF, Forster RE: Cyclic variation of rate of carbon monoxide production in normal women. J Appl Physio/ 1974 $36: 49-51$. 
111. Nishibayashi H, Sato R: Preparation of hepatic microsomal particles containing P-450 as the sole heme constituent and absolute spectra of P-450. J Biochem 1968, 63:766-779.

112. Vreman HJ, Wong RJ, Sanesi CA, Dennery PA, Stevenson DK: Simultaneous production of carbon monoxide and thiobarbituric acid reactive substances in rat tissue preparations by an iron-ascorbate system. Can $J$ Physiol Pharmacol 1998, 76:1057-1065

113. Wolff DG: The formation of carbon monoxide during peroxidation of microsomal lipids. Biochem Biophys Res Commun 1976, 73:850-857.

114. Wu L, Wang R: Carbon monoxide: endogenous production, physiological functions, and pharmacological applications. Pharmacol Rev 2005, 57:585-630.

115. Tenhunen R, Marver HS, Schmid R: The enzymatic conversion of hemoglobin to bilirubin. Trans Assoc Am Physicians 1969, 82:363-371.

116. Higashimoto Y, Sakamoto H, Hayashi S, Sugishima M, Fukuyama K, Palmer G Noguchi M: Involvement of NADPH in the interaction between heme oxygenase- 1 and cytochrome P450 reductase. J Biol Chem 2005, 280:729-737.

117. Maines MD, Kappas A: Cobalt induction of hepatic heme oxygenase; with evidence that cytochrome P-450 is not essential for this enzyme activity. Proc Natl Acad Sci USA 1974, 71:4293-4297.

118. Yoshida T, Takahashi S, Kikuchi G: Partial purification and reconstitution of the heme oxygenase system from pig spleen microsomes. J Biochem 1974, 75:1187-1191.

119. Maines MD: The heme oxygenase system: a regulator of second messenger gases. Annu Rev Pharmacol Toxicol 1997, 37:517-554.

120. McCoubrey WK Jr, Huang TJ, Maines MD: Isolation and characterization of a cDNA from the rat brain that encodes hemoprotein heme oxygenase3. Eur J Biochem 1997, 247:725-732

121. Agarwal A, Nick HS: Renal response to tissue injury: lessons from heme oxygenase-1 GeneAblation and expression. J Am Soc Nephrol 2000, 11:965-973.

122. Hayashi S, Omata $Y$, Sakamoto H, Higashimoto $Y$, Hara T, Sagara $Y$, Noguchi $\mathrm{M}$ : Characterization of rat heme oxygenase-3 gene. Implication of processed pseudogenes derived from heme oxygenase- 2 gene. Gene 2004, 336:241-250

123. Zhou H, Liu H, Porvasnik SL, Terada N, Agarwal A, Cheng Y, Visner GA: Heme oxygenase-1 mediates the protective effects of rapamycin in monocrotaline-induced pulmonary hypertension. Lab Invest 2006, 86:62-71.

124. Inguaggiato P, Gonzalez-Michaca L, Croatt AJ, Haggard JJ, Alam J, Nath KA: Cellular overexpression of heme oxygenase-1 up-regulates p21 and confers resistance to apoptosis. Kidney Int 2001, 60:2181-2191.

125. Ryter SW, Tyrrell RM: The heme synthesis and degradation pathways: role in oxidant sensitivity. Heme oxygenase has both pro- and antioxidant properties. Free Radic Biol Med 2000, 28:289-309.

126. Lundvig DM, Immenschuh S, Wagener FA: Heme oxygenase, inflammation, and fibrosis: the good, the bad, and the ugly? Front Pharmacol 2012, 3:81.

127. Poss KD, Thomas MJ, Ebralidze AK, O'Dell TJ, Tonegawa S: Hippocampal long-term potentiation is normal in heme oxygenase-2 mutant mice. Neuron 1995, 15:867-873.

128. Poss KD, Tonegawa S: Heme oxygenase 1 is required for mammalian iron reutilization. Proc Natl Acad Sci USA 1997, 94:10919-10924.

129. Poss KD, Tonegawa S: Reduced stress defense in heme oxygenase 1-deficient cells. Proc Natl Acad Sci USA 1997, 94:10925-10930.

130. Yachie A, Niida Y, Wada T, Igarashi N, Kaneda H, Toma T, Ohta K, Kasahara Y, Koizumi S: Oxidative stress causes enhanced endothelial cell injury in human heme oxygenase-1 deficiency. J Clin Invest 1999, 103:129-135.

131. Verma A, Hirsch DJ, Glatt CE, Ronnett GV, Snyder SH: Carbon monoxide: a putative neural messenger. Science 1993, 259:381-384.

132. Siriussawakul A, Chen LI, Lang JD: Medical gases: a novel strategy for attenuating ischemia-reperfusion injury in organ transplantation? J Transplant 2012, 2012:819382.

133. Ramos KS, Lin H, McGrath JJ: Modulation of cyclic guanosine monophosphate levels in cultured aortic smooth muscle cells by carbon monoxide. Biochem Pharmacol 1989, 38:1368-1370.

134. Utz J, Ullrich V: Carbon monoxide relaxes ileal smooth muscle through activation of guanylate cyclase. Biochem Pharmacol 1991, 41:1195-1201.

135. Morita T, Kourembanas S: Endothelial cell expression of vasoconstrictors and growth factors is regulated by smooth muscle cell-derived carbon monoxide. J Clin Invest 1995, 96:2676-2682.
136. Morita T, Mitsialis SA, Koike H, Liu Y, Kourembanas S: Carbon monoxide controls the proliferation of hypoxic vascular smooth muscle cells. J Biol Chem 1997, 272:32804-32809.

137. Brune B, Ullrich V: Inhibition of platelet aggregation by carbon monoxide is mediated by activation of guanylate cyclase. Mol Pharmacol 1987, 32:497-504.

138. Gunther L, Berberat PO, Haga M, Brouard S, Smith RN, Soares MP, Bach FH, Tobiasch E: Carbon monoxide protects pancreatic beta-cells from apoptosis and improves islet function/survival after transplantation. Diabetes 2002, 51:994-999.

139. Queiroga CS, Almeida AS, Martel C, Brenner C, Alves PM, Vieira HL: Glutathionylation of adenine nucleotide translocase induced by carbon monoxide prevents mitochondrial membrane permeabilization and apoptosis. J Biol Chem 2010, 285:17077-17088.

140. Zuckerbraun BS, Chin BY, Bilban M, D'Avila JC, Rao J, Billiar TR, Otterbein LE: Carbon monoxide signals via inhibition of cytochrome $c$ oxidase and generation of mitochondrial reactive oxygen species. FASEB J 2007, 21:1099-1106

141. Almeida AS, Queiroga CS, Sousa MF, Alves PM, Vieira HL: Carbon monoxide modulates apoptosis by reinforcing oxidative metabolism in astrocytes: role of Bcl-2. J Biol Chem 2012, 287:10761-10770.

142. Brouard S, Otterbein LE, Anrather J, Tobiasch E, Bach FH, Choi AM, Soares MP: Carbon monoxide generated by heme oxygenase 1 suppresses endothelial cell apoptosis. J Exp Med 2000, 192:1015-1026.

143. Song R, Zhou Z, Kim PK, Shapiro RA, Liu F, Ferran C, Choi AM, Otterbein LE: Carbon monoxide promotes Fas/CD95-induced apoptosis in Jurkat cells J Biol Chem 2004, 279:44327-44334.

144. Otterbein LE, Choi AM: Heme oxygenase: colors of defense against cellular stress. Am J Physiol Lung Cell Mol Physiol 2000, 279:L1029-1037.

145. Durante W, Kroll MH, Christodoulides N, Peyton KJ, Schafer Al: Nitric oxide induces heme oxygenase-1 gene expression and carbon monoxide production in vascular smooth muscle cells. Circ Res 1997, 80:557-564.

146. Zuckerbraun BS, Otterbein LE, Boyle P, Jaffe R, Upperman J, Zamora R, Ford HR: Carbon monoxide protects against the development of experimental necrotizing enterocolitis. Am J Physiol Gastrointest Liver Physiol 2005 289:G607-613.

147. White KA, Marletta MA: Nitric oxide synthase is a cytochrome P-450 type hemoprotein. Biochemistry 1992, 31:6627-6631.

148. Otterbein LE: The evolution of carbon monoxide into medicine. Respir Care 2009, 54:925-932

149. Chauveau C, Bouchet D, Roussel JC, Mathieu P, Braudeau C, Renaudin K, Tesson L, Soulillou JP, Iyer S, Buelow R, Anegon I: Gene transfer of heme oxygenase-1 and carbon monoxide delivery inhibit chronic rejection. Am J Transplant 2002, 2:581-592.

150. Motterlini R, Clark JE, Foresti R, Sarathchandra P, Mann BE, Green CJ: Carbon monoxide-releasing molecules: characterization of biochemical and vascular activities. Circ Res 2002, 90:E17-24.

151. Clark JE, Naughton P, Shurey S, Green CJ, Johnson TR, Mann BE, Foresti R, Motterlini R: Cardioprotective actions by a water-soluble carbon monoxide-releasing molecule. Circ Res 2003, 93:e2-8.

152. Motterlini R, Sawle P, Hammad J, Bains S, Alberto R, Foresti R, Green CJ: CORM-A1: a new pharmacologically active carbon monoxide-releasing molecule. FASEB J 2005, 19:284-286.

153. Zimmermann A, Leffler CW, Tcheranova D, Fedinec AL, Parfenova $H$ : Cerebroprotective effects of the CO-releasing molecule CORM-A1 against seizure-induced neonatal vascular injury. Am J Physiol Heart Circ Physiol 2007, 293:H2501-2507.

154. Fagone P, Mangano K, Quattrocchi C, Motterlini R, Di Marco R, Magro G, Penacho N, Romao CC, Nicoletti F: Prevention of clinical and histological signs of proteolipid protein (PLP)-induced experimental allergic encephalomyelitis (EAE) in mice by the water-soluble carbon monoxidereleasing molecule (CORM)-A1. Clin Exp Immunol 2011, 163:368-374.

155. Ryan MJ, Jernigan NL, Drummond HA, McLemore GR Jr, Rimoldi JM, Poreddy SR, Gadepalli RS, Stec DE: Renal vascular responses to CORM-A1 in the mouse. Pharmacol Res 2006, 54:24-29.

156. Chlopicki S, Lomnicka M, Fedorowicz A, Grochal E, Kramkowski K, Mogielnicki A, Buczko W, Motterlini R: Inhibition of platelet aggregation by carbon monoxide-releasing molecules (CO-RMs): comparison with NO donors. Naunyn Schmiedebergs Arch Pharmacol 2012, 385:641-650.

157. Kramkowski K, Leszczynska A, Mogielnicki A, Chlopicki S, Fedorowicz A, Grochal E, Mann B, Brzoska T, Urano T, Motterlini R, Buczko W: 
Antithrombotic properties of water-soluble carbon monoxide-releasing molecules. Arterioscler Thromb Vasc Biol 2012, 32:2149-2157.

158. Desmard M, Foresti R, Morin D, Dagouassat M, Berdeaux A, Denamur E, Crook SH, Mann BE, Scapens D, Montravers P, et al: Differential antibacterial activity against Pseudomonas aeruginosa by carbon monoxide-releasing molecules. Antioxid Redox Signal 2011, 16:153-163.

159. Kinderlerer AR, Pombo Gregoire I, Hamdulay SS, Ali F, Steinberg R, Silva G, Ali N, Wang B, Haskard DO, Soares MP, Mason JC: Heme oxygenase-1 expression enhances vascular endothelial resistance to complementmediated injury through induction of decay-accelerating factor: a role for increased bilirubin and ferritin. Blood 2009, 113:1598-1607.

160. Tsoyi K, Nizamutdinova IT, Jang HJ, Mun L, Kim HJ, Seo HG, Lee JH, Chang KC: Carbon monoxide from CORM-2 reduces HMGB1 release through regulation of IFN-beta/JAK2/STAT-1/INOS/NO signaling but not COX-2 in TLR-activated macrophages. Shock 2010, 34:608-614.

161. Remy S, Blancou P, Tesson L, Tardif V, Brion R, Royer PJ, Motterlini R, Foresti $R$, Painchaut $M$, Pogu S, et al: Carbon monoxide inhibits TLR-induced dendritic cell immunogenicity. J Immunol 2009, 182:1877-1884.

162. Nakahira K, Kim HP, Geng XH, Nakao A, Wang X, Murase N, Drain PF, Wang X, Sasidhar M, Nabel EG, et al: Carbon monoxide differentially inhibits TLR signaling pathways by regulating ROS-induced trafficking of TLRs to lipid rafts. J Exp Med 2006, 203:2377-2389.

163. Wang X, Cao J, Sun BW, Liu DD, Liang F, Gao L: Exogenous carbon monoxide attenuates inflammatory responses in the small intestine of septic mice. World J Gastroenterol 2012, 18:5719-5728.

164. Ning W, Choi AM, Li C: Carbon monoxide inhibits IL-17-induced IL-6 production through the MAPK pathway in human pulmonary epithelial cells. Am J Physiol Lung Cell Mol Physiol 2005, 289:L268-273.

165. Pae HO, Oh GS, Choi BM, Chae SC, Kim YM, Chung KR, Chung HT: Carbon monoxide produced by heme oxygenase-1 suppresses $\mathrm{T}$ cell proliferation via inhibition of IL-2 production. I Immunol 2004, 172:4744-4751.

166. Amersi F, Shen XD, Anselmo D, Melinek J, lyer S, Southard DJ, Katori M, Volk $H D$, Busuttil RW, Buelow R, Kupiec-Weglinski JW: Ex vivo exposure to carbon monoxide prevents hepatic ischemia/reperfusion injury through p38 MAP kinase pathway. Hepatology 2002, 35:815-823.

167. Otterbein LE, Otterbein SL, Ifedigbo E, Liu F, Morse DE, Fearns C, Ulevitch RJ, Knickelbein R, Flavell RA, Choi AM: MKK3 mitogen-activated protein kinase pathway mediates carbon monoxide-induced protection against oxidant-induced lung injury. Am J Pathol 2003, 163:2555-2563.

168. Takagi T, Naito Y, Uchiyama K, Okuda T, Suzuki T, Tsuboi H, Mizushima K, Handa O, Yagi N, Ichikawa H, Yoshikawa T: Colonic insufflation with carbon monoxide gas inhibits the development of intestinal inflammation in rats. Med Gas Res 2012, 2:23.

169. Wegiel B: Hanto DW. Otterbein LE: The social network of carbon monoxide in medicine. Trends Mol Med; 2012

170. Chora AA, Fontoura P, Cunha A, Pais TF, Cardoso S, Ho PP, Lee LY, Sobel RA, Steinman L, Soares MP: Heme oxygenase- 1 and carbon monoxide suppress autoimmune neuroinflammation. J Clin Invest 2007, 117:438-447.

171. Simon T, Pogu S, Tardif V, Rigaud K, Remy S, Piaggio E, Bach JM, Anegon I, Blancou P: Carbon monoxide-treated dendritic cells decrease beta1integrin induction on CD8(+) T cells and protect from type 1 diabetes. Eur J Immunol 2012.

172. Goldberg A, Parolini M, Chin BY, Czismadia E, Otterbein LE, Bach FH, Wang $\mathrm{H}$ : Toll-like receptor 4 suppression leads to islet allograft survival. FASEB $J$ 2007, 21:2840-2848

173. Clarke HM, Shrivastava S, Motterlini R, Sawle P, Chen D, Dorling A: Donor HO-1 expression inhibits intimal hyperplasia in unmanipulated graft recipients: a potential role for $\mathrm{CD} 8+\mathrm{T}$-cell modulation by carbon monoxide. Transplantation 2009, 88:653-661.

174. Akamatsu Y, Haga M, Tyagi S, Yamashita K, Graca-Souza AV, Ollinger R, Czismadia E, May GA, Ifedigbo E, Otterbein LE, et al: Heme oxygenase1-derived carbon monoxide protects hearts from transplant associated ischemia reperfusion injury. FASEB J 2004, 18:771-772.

175. Martins PN, Reuzel-Selke A, Jurisch A, Atrott K, Pascher A, Pratschke J, Buelow R, Neuhaus P, Volk HD, Tullius SG: Induction of carbon monoxide in the donor reduces graft immunogenicity and chronic graft deterioration. Transplant Proc 2005, 37:379-381.

176. Caumartin Y, Stephen J, Deng JP, Lian D, Lan Z, Liu W, Garcia B, Jevnikar AM, Wang H, Cepinskas G, Luke PP: Carbon monoxide-releasing molecules protect against ischemia-reperfusion injury during kidney transplantation. Kidney Int 2011, 79:1080-1089.
177. Goncalves GM, Cenedeze MA, Feitoza CQ, Wang PM, Bertocchi AP, Damiao MJ, Pinheiro HS, Antunes Teixeira VP, Dos Reis MA, Pacheco-Silva A, Camara NO: The role of heme oxygenase 1 in rapamycin-induced renal dysfunction after ischemia and reperfusion injury. Kidney Int 2006, 70:1742-1749

178. Bernhardt WM, Campean V, Kany S, Jurgensen JS, Weidemann A, Warnecke C, Arend M, Klaus S, Gunzler V, Amann K, et al: Preconditional activation of hypoxia-inducible factors ameliorates ischemic acute renal failure. J Am Soc Nephrol 2006, 17:1970-1978.

179. Nakao A, Toyokawa H, Tsung A, Nalesnik MA, Stolz DB, Kohmoto J, Ikeda A, Tomiyama K, Harada T, Takahashi T, et al: Ex vivo application of carbon monoxide in University of Wisconsin solution to prevent intestinal cold ischemia/reperfusion injury. Am J Transplant 2006, 6:2243-2255.

180. Faleo G, Neto JS, Kohmoto J, Tomiyama K, Shimizu H, Takahashi T, Wang Y, Sugimoto R, Choi AM, Stolz DB, et al: Carbon monoxide ameliorates renal cold ischemia-reperfusion injury with an upregulation of vascular endothelial growth factor by activation of hypoxia-inducible factor. Transplantation 2008, 85:1833-1840.

181. Nakao A, Huang CS, Stolz DB, Wang Y, Franks JM, Tochigi N, Billiar TR, Toyoda Y, Tzeng E, McCurry KR: Ex vivo carbon monoxide delivery inhibits intimal hyperplasia in arterialized vein grafts. Cardiovasc Res 2011, 89:457-463.

182. Nakao A, Kimizuka K, Stolz DB, Neto JS, Kaizu T, Choi AM, Uchiyama T, Zuckerbraun BS, Nalesnik MA, Otterbein LE, Murase N: Carbon monoxide inhalation protects rat intestinal grafts from ischemia/reperfusion injury. Am J Pathol 2003, 163:1587-1598.

183. Nakao A, Kimizuka K, Stolz DB, Seda Neto J, Kaizu T, Choi AM, Uchiyama T, Zuckerbraun BS, Bauer AJ, Nalesnik MA, et al: Protective effect of carbon monoxide inhalation for cold-preserved small intestinal grafts. Surgery 2003, 134:285-292

184. Lee LY, Kaizu T, Toyokawa H, Zhang M, Ross M, Stolz DB, Huang C, Gandhi C, Geller DA, Murase N: Carbon monoxide induces hypothermia tolerance in Kupffer cells and attenuates liver ischemia/reperfusion injury in rats. Liver Transp/ 2011, 17:1457-1466.

185. Vera T, Henegar JR, Drummond HA, Rimoldi JM, Stec DE: Protective effect of carbon monoxide-releasing compounds in ischemia-induced acute renal failure. J Am Soc Nephrol 2005, 16:950-958.

186. Wei Y, Chen P, de Bruyn M, Zhang W, Bremer E, Helfrich W: Carbon monoxide-releasing molecule-2 (CORM-2) attenuates acute hepatic ischemia reperfusion injury in rats. BMC Gastroenterol 2010, 10:42.

187. Musameh MD, Green CJ, Mann BE, Fuller BJ, Motterlini R: Improved myocardial function after cold storage with preservation solution supplemented with a carbon monoxide-releasing molecule (CORM-3). $J$ Heart Lung Transplant 2007, 26:1192-1198.

188. Pizarro MD, Rodriguez JV, Mamprin ME, Fuller BJ, Mann BE, Motterlini R, Guibert EE: Protective effects of a carbon monoxide-releasing molecule (CORM-3) during hepatic cold preservation. Cryobiology 2009, 58:248-255.

189. Song H, Hoeger S, Hillebrands JL, Mandel I, Loesel R, Beck G, Schilling L, Schnuelle $P$, Yard B: CORMs protect endothelial cells during cold preservation, resulting in inhibition of intimal hyperplasia after aorta transplantation in rats. Transpl Int 2010, 23:1144-1153.

190. Nakao A, Neto JS, Kanno S, Stolz DB, Kimizuka K, Liu F, Bach FH, Billiar TR, Choi AM, Otterbein LE, Murase N: Protection against ischemia/reperfusion injury in cardiac and renal transplantation with carbon monoxide, biliverdin and both. Am J Transplant 2005, 5:282-291.

191. Chen B, Guo L, Fan C, Bolisetty S, Joseph R, Wright MM, Agarwal A, George JF: Carbon monoxide rescues heme oxygenase-1-deficient mice from arterial thrombosis in allogeneic aortic transplantation. Am J Pathol 2009, 175:422-429.

192. Neto JS, Nakao A, Kimizuka K, Romanosky AJ, Stolz DB, Uchiyama T, Nalesnik MA, Otterbein LE, Murase N: Protection of transplant-induced renal ischemia-reperfusion injury with carbon monoxide. Am J Physiol Renal Physiol 2004, 287:F979-989.

193. Neto JS, Nakao A, Toyokawa H, Nalesnik MA, Romanosky AJ, Kimizuka K, Kaizu T, Hashimoto N, Azhipa O, Stolz DB, et al: Low-dose carbon monoxide inhalation prevents development of chronic allograft nephropathy. Am J Physiol Renal Physiol 2006, 290:F324-334.

194. Song R, Kubo M, Morse D, Zhou Z, Zhang X, Dauber JH, Fabisiak J, Alber SM, Watkins SC, Zuckerbraun BS, et al: Carbon monoxide induces cytoprotection in rat orthotopic lung transplantation via antiinflammatory and anti-apoptotic effects. Am J Pathol 2003, 163:231-242. 
195. Nakao A, Moore BA, Murase N, Liu F, Zuckerbraun BS, Bach FH, Choi AM, Nalesnik MA, Otterbein LE, Bauer AJ: Immunomodulatory effects of inhaled carbon monoxide on rat syngeneic small bowel graft motility. Gut 2003, 52:1278-1285.

196. Kaizu T, Nakao A, Tsung A, Toyokawa H, Sahai R, Geller DA, Murase N: Carbon monoxide inhalation ameliorates cold ischemia/reperfusion injury after rat liver transplantation. Surgery 2005, 138:229-235.

197. Ke B, Buelow R, Shen XD, Melinek J, Amersi F, Gao F, Ritter T, Volk HD, Busuttil RW, Kupiec-Weglinski JW: Heme oxygenase 1 gene transfer prevents CD95/Fas ligand-mediated apoptosis and improves liver allograft survival via carbon monoxide signaling pathway. Hum Gene Ther 2002, 13:1189-1199.

198. Sato K, Balla J, Otterbein L, Smith RN, Brouard S, Lin Y, Csizmadia E, Sevigny J, Robson SC, Vercellotti G, et al: Carbon monoxide generated by heme oxygenase-1 suppresses the rejection of mouse-to-rat cardiac transplants. J Immunol 2001, 166:4185-4194.

199. Otterbein LE, Zuckerbraun BS, Haga M, Liu F, Song R, Usheva A, Stachulak C, Bodyak N, Smith RN, Csizmadia E, et al: Carbon monoxide suppresses arteriosclerotic lesions associated with chronic graft rejection and with balloon injury. Nat Med 2003, 9:183-190.

200. Lee SS, Gao W, Mazzola S, Thomas MN, Csizmadia E, Otterbein LE, Bach FH, Wang H: Heme oxygenase-1, carbon monoxide, and bilirubin induce tolerance in recipients toward islet allografts by modulating $\mathrm{T}$ regulatory cells. FASEB J 2007, 21:3450-3457.

201. Zhou L, Liu Y, Zou C, Ma N, Hui Y, Lv G, Zhang H, Zhou H, Gao X: The effect of the Gly139His, Gly143His, and Ser142His mouse heme oxygenase-1 mutants on the $\mathrm{HO}$ reaction in vivo and in vitro. Anat Rec (Hoboken) 2010, 294:112-118

202. Hanto DW, Maki T, Yoon MH, Csizmadia E, Chin BY, Gallo D, Konduru B, Kuramitsu K, Smith NR, Berssenbrugge A, et al: Intraoperative administration of inhaled carbon monoxide reduces delayed graft function in kidney allografts in Swine. Am J Transplant 2010, 10:2421-2430.

doi:10.1186/2045-9912-3-1

Cite this article as: Amano and Camara: The immunomodulatory role of carbon monoxide during transplantation. Medical Gas Research 2013 3:1.

\section{Submit your next manuscript to BioMed Central and take full advantage of:}

- Convenient online submission

- Thorough peer review

- No space constraints or color figure charges

- Immediate publication on acceptance

- Inclusion in PubMed, CAS, Scopus and Google Scholar

- Research which is freely available for redistribution 